BNWL-206

\title{
EXPERIMENTAL. BOILING BURNOUT HEAT FLUXES WITH AN ELECTRICALLY HEATED 19-ROD BUNDLE TEST SECTION
}

\section{DEVELOPMENT} PEPORT

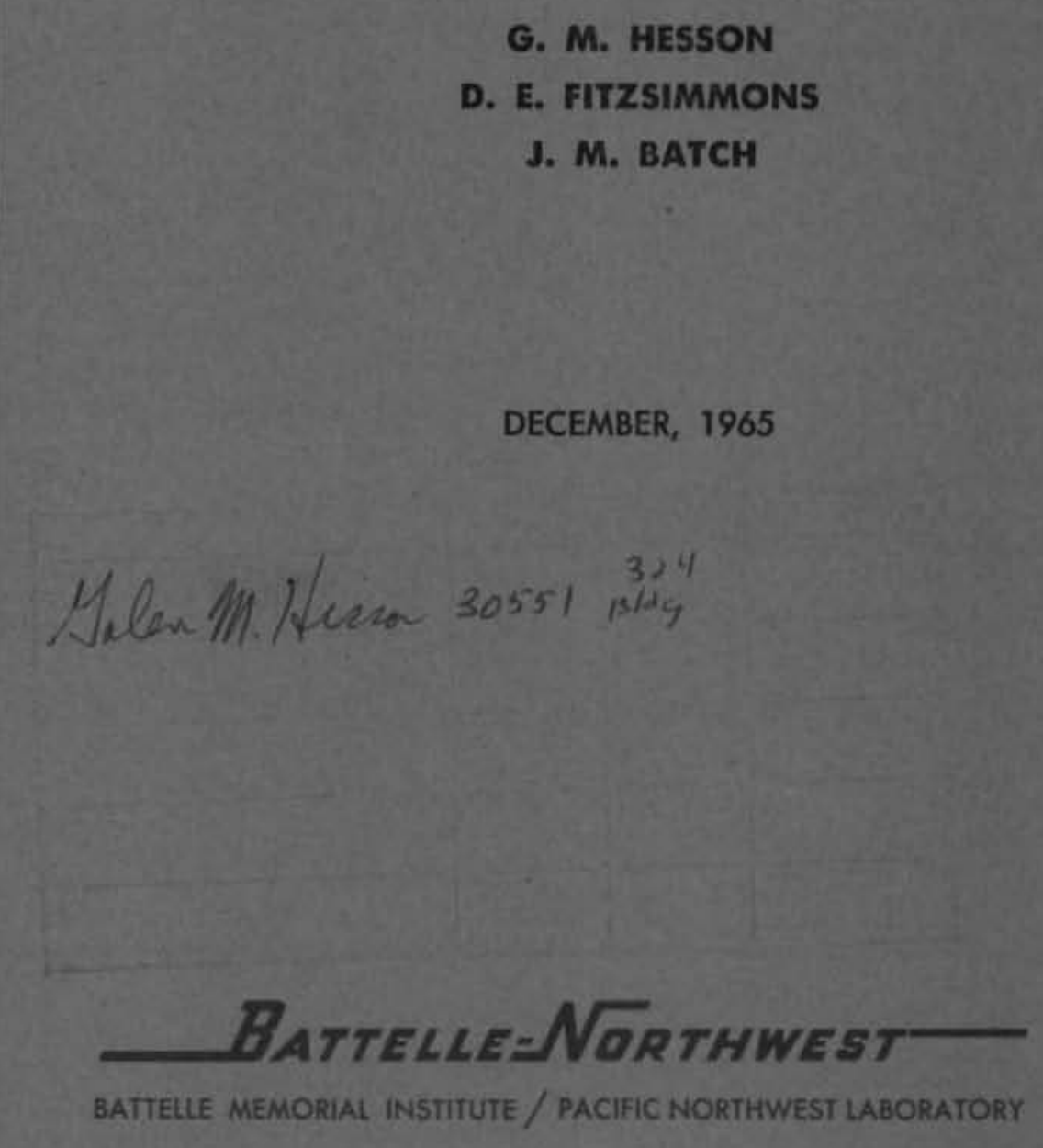




\section{LEGAL NOTICE}

This report was prepored as an account of Government sponsored work. Neither the Unifed States, nor the Commission, nor any person acting on behalf of the Cominission:

A. Makes any warranty or representation, expressed or implied, with respect to the accuracy, completeness, or usefulness of the information contained in this report, or that the use of any information, apporatus, method, or process disclosed in this repont may not infringe privately owned rights; or

B. Assumes any liabilities with respect to the use of, or for domages resulting from the use of any information, apporatus, method, or process disclosed in this reporf.

As used in the above, "person acting on behalf of the Commission" includes any emplayee or contractor of the Commission, or employee of such contractor, to the extent that such employee or contractor of the Commission, or employee of such contractor prepares, disseminotes, or provides access 10. any information pursuant to his employment or controct with the Commission, or his employment with such confractor.

\section{PACIFIC NORTHWEST LABORATORY \\ RICHLAND, WASHINGTON \\ operated by \\ BATTELLE MEMORIAL INSTITUTE}

for the

UNITED STATES ATOMIC ENERGY COMMISSION UNDER CONTRACT AT(45-1)-1830 
BNWL-206

UC-38, Engineering and Equipment

\author{
EXXPEIMENTAL BOILING BURNOUT HEAT FLUXES \\ WITH AN ELECTRICALLY HEATED \\ 19-ROD BUNDLE TEST SECTION
}

By

G. M. Hesson

D. E. Fitzsimmons

J. M. Batch

Thermal Hydraulics Unit

Reactor Engineering Section

Reactor and Materials Technology Department

December, 1965

This document is furnished pursuant to the Memorandum of Understanding of June 7, 1960, between the U. S. and Canadian Governments, establishing a cooperative program on the development of heavy water moderated power reactors. 
$\cdot$

Printed in USA. Price $\$ 3.00$. Available from the Clearinghouse for Federal Scientific and Technical Information National Bureau of Standards

U. S. Department of Commerce Springfield, Virginia 


\section{EXPERIMENTAL BOILING BURNOUT HEAT FLUXES \\ WITH AN ELECTRICAILY HEATED \\ 19-ROD BUNDLE TEST SECTION}

\section{INTRODUCTION}

A nuclear reactor fuel element made of a bundle of rods is attractive because its fabrication is relatively simple, and it provides a large heat transfer area to fuel volume and can, therefore, support relatively large power densities without excessive heat transfer rates. The thermal-hydraulic behavior of such fuel elements is quite complex. however. In general, any change in the design of such a fuel element requires experimentation to define its thermal-hydraulic behavior, and in particular, its bolling burnout characteristics. 1

Heat transfer characteristics of 19-rod bundles have been studied before. $(1,2,3,4,5)$ mis report presents the results of further experiments with a 19-rod bundle fuel element and reports effects of introduc Ing the coolant as a steam-water mixture ( $f \circ g$ cooling), using a device to concentrate the water at the center of the bunde, and using roughen=. ing rings on the inside of the pressure tube to displace the liquid film.

$I_{\text {The term boiling burnout is used in this report as a generic term des }}$ cribing a large degradation of the heat transfer coefficient with small. changes in the thermal-hydraulic variables. It is recognized that different mechanisms at different conditions are involved in boiling burnout. 


\section{SUMMARY AND CONCLUSIONS}

A total of 76 boillng burnout experiments was made with an electrically heated model of a 19-rod bundle fuel element. The test section had a heated length of $6.3 \mathrm{ft}$ and was made up of $0.612 \mathrm{in.}$ OD rods spaced 0.040 in. apart by means of warts. The spacing between the test section and the $3.25 \mathrm{in.}$ ID flow housing tube was 0.060 in.

The tests were made under a variety of conditions including two pressures, both rough and smooth wall flow housing, both subcooled and fog (wet steam) inlet coolant, and two inlet piping configurations. A summary of the combinations of these conditions used is given in Table I. The experiments were made at coolant flow rates from $1,000,000$ to $3,000,000 \mathrm{lb} / \mathrm{hr}^{-\mathrm{ft}^{2}}$, and with coolant inlet conditions ranging from $300^{\circ} \mathrm{F}$ subcooled to $40 \%$ quality steam.

The conclusions to be made from these experiments are:

- In general, the plots of the data for fog inlet cases gave smooth extensions of the plots of data for subcooled inlet cases for the same flow rate. This indicates that there is nothing unique about the use of fog coolant with the physical arrangement used in these tests.

- The use of rougheners on the flow tube wall increased the boiling burnout from 10 to $35 \%$, based on the same outlet enthalpy. When the rougheners were used, the magnitude of the temperature excursions upon the start of boiling burn out tended to be less than those found with the smooth wall tests. 
- A preferred placement of the water on the heated surfaces at the inlet of the test section during the fog inlet tests had no effect on boiling burnout. Apparently, the beneficial effects of the preferred placing of the water were dissipated by the time the coolant had traveled the length of the test section.

- The boiling burnout heat fluxes obtained with this test section showed a smaller dependence on enthalpy than was found in previous tests with a similar test section, but with $0.050 \mathrm{in}$. spacing between rods and $0.100 \mathrm{in}$. spacing between test section and flow housing wall. The boiling burnout heat fluxes with the present test section were lower at the lower outlet enthalpies and about the same at the higher enthalpies than were those from the previous tests. This was in spite of the fact that the present test section is calculated to have a smaller enthalpy disparity across a cross section of the test section than had the previous test section.

- Decreasing the pressure from 1200 psia to 1000 psia caused an increase in the boiling burnout heat flux on the order of $10 \%$.

- Boiling burnout occurred on the center rod when the outlet enthalpy was low. It occurred on any one, and usually on several, of the inner seven rods when the outlet enthalpy was high. 


\section{EXPERIMENTAL EQUIPMENT:}

\section{Test Section}

The test section consisted of nineteen 0.612 in oD Inconel tubes, 76 in. long, arranged in concentric rings of 6 and i2 rods around a cen. tral rod (Flgure 1). The wall thickness of the tubes was such that the test section would produce a radial heat flux distribution in which the Inner 7 rods had heat fluxes $80.5 \%$ of that of the outer 12 rods. The spacing between adjacent rods was malntained by means of ceramic warts at $93 / 4$ in. Intervals. The warts were attached to the rods with a slotted sleeve silver soldered to the rods. Details of the warts and ferrules are shown in Figures $2 \mathrm{~A}$ and $2 \mathrm{~B}$. The bundie was placed in a flow housing 3.25 in. ID with a radiai spacing of 0.060 in between the outside rods and the flow housing. The ficw housing, in turn, was placed within a stainiess steel pipe which contained the pressure of the coolant. The flow housing consisted of spilt ceramic eylinders 3 in. long placed around the test section viton orings heid the half cylinders together and sealed the gav between the oD of the cyinders and the ID of the pressure tube. Split ceramic rings were made that could be inserted between the ceramic cylinders of the flow housing to provide a roughened flow housing wail. wher these rings were instalied, the flow housing was provided with circumferential ridges 0.050 in high by 0.075 in. long protruding ant the flow stream every 3.25 in. (Figure 3).

A thermocouple was installed at the outlet end of each rod (Figure 4). The thermocouple was imbedded in a $3 / 8$ in long copper cylinder whose OD was coated with a ceramic and which fit snugly within 
the heater tubes. In case of a local hot spot on the tube surface, the cylinder was grooved both circumferentially and axially to direct the heat flow within the copper to the thermocouple. With this installation, the thermocouples read an average of the rod wall temperature over the last $3 / 8 \mathrm{in}$. of its length.

The electrical connection at the inlet of the test section was constructed so that the electrical path was through the side of the pressure tube. This was accomplished by extending each heater rod inlet end with a solid copper rod $163 / 4$ in. long and with the same OD as had the heater rods. The first $63 / 4 \mathrm{in}$. of the copper pieces were interconnected with brazed $1 / 8$ in. copper webs. The outer 12 rods were connected with Identical copper webs to a nickel sleeve whose ID was 3.25 in., the same as that of the flow housing. The electrical power leads were connected to the nickel sleeve. In this manner, the coolant flow disturbances caused by the presence of the electrical connectors were minimized, and the inlet end of the test section was reasonably prototypical of a nuclear reactor fuel element in a pressure tube.

\section{Inlet Device}

The test section was provided with a special inlet device designed and constructed by the AECL. It was used for both the subcooled and fog-cooled runs, but served as a coolant flow conditioner only during the fog-cooled runs. During the fog-cooled runs, two coolant streams were delivered to the test section: one a slightly subcooled stream and the other a stream of nearly saturated steam. The inlet device combined the two streams and delivered them to the inlet end of the test section. 
The inlet device was provided with two sets of internal components. One set mixed the water and steam thoroughly and delivered a homogeneous steam-water mixture to the test section inlet. The other set was designed to keep the water and steam streams separated, and it delivered a high water content stream into the bunde and a low water content stream into the space between the bundle and pressure tube wall. Hence, most of the water was placed on the heated surfaces of the bunde, and little was wasted on the cold walls of the pressure tube. In this mode of operation, the inlet device is called a concentrator.

Preheater and Steam Generator

The experimental equipment included an electrical preheater. One of the two power sources of the PNL heat transfer laboratories was connected to this preheater while the other was connected to the test section. During the subcooled runs, all of the coolant passed through the preheater, which was used to adjust the temperature of the coolant to the test section. A simplified schematic of the preheater and test section set up for the fog-cocled runs is shown in Figure 5.

During the fogmcooled runs, however, the coslant stream was split in two (Figure 6). Part of the coolant at about $40^{\circ} \mathrm{F}$ subcooling was delivered to the water port of the inlet device. The rest of the cool ant was directed through the preheater, where it was heated to nearly saturated steam conditions; through a valve, across which a 200 psi differential was maintained; and then to the steam port of the inlet device. 


\section{General}

The test section was operated in the heat transfer laboratory of PNL. (6)

\section{EXPERIMENTAL PROCEDURE}

The experiments were performed by establishing a flow rate and inlet enthalpy with a heat flux on the test section below the boiling burnout heat flux. The power to the test section was then increased in a series of steps until boiling burnout was reached. Data were taken at each power step. The size of the steps varied, but at conditions near boiling burnout, the steps were such to give increases in the heat flux of 5,000 to $20,000 \mathrm{Btu} / \mathrm{hr}-\mathrm{ft}^{2}$.

\section{EXPERIMENTAL RESULTS}

The tests included investigating boiling burnout heat fluxes for both fog-cooled and subcooled inlet conditions, with smooth and rough pressure tube walls, with the inlet device functioning both as a homogenizer and concentrator, and at pressures of both 1000 and 1200 psia. The combinations of these various conditions that were investigated are summarized in Table I.

The experimental results are summarized in:

- Table II, giving the results for Conditions $I$ and 7 of Table I

- Table III, giving the results for Conditions 3 and 4 of Table I

- Table IV, giving the results for Condition 2 of Table I

- Table V, giving the results for Conditions 5 and 6 of Table I 


\section{DISCUSSION}

\section{Definition of Bolling Burnout}

The start of bolling burnout was determined from the wall temperatures of the 19 rods. Under nonburnout conditions, the temperature increases were on the order of $1-3^{\circ} \mathrm{F}$ following each power increase. In most cases, the onset of bolling burnout was indlcated by a temperature excursion of 20 to $80^{\circ} \mathrm{F}$ on one or more rods during the power increase. In general, the temperatures would level out to a reasonably steady value, and operation in a condition of bolling burnout continued until all of the data were recorded. In many cases, however, the start of f1lm bolling was typifled by much smaller rod temperature increases, perhaps as small as $5^{\circ} \mathrm{F}$. In these cases, several power increase steps were made beyond that at which the start of bolling burnout was first suspected. It must be remembered that the thermocouple instellation used in these tests was such that they read an average circumferential temperature. For example, a $5^{\circ} \mathrm{F}$ rise could result from a $20^{\circ} \mathrm{F}$ rise over a quarter of the circumference, with no rise over the remainder.

To provide a consistent method of defining bolling burnout, plots of rod wall temparatures vs, heat fluxes were made. Buch plots yielded stralght lines for the nonburnout heat fluxes. Bo1ling burnout 1s ind1cated by a ingle point away from the straight ine when the temperature excursions were large. Plots of th1 type are shown in P1gures 7 and 8 . Boiling burnout, however, was Indlcated by a gradual curving away of the data points from an extension of the straight-line portion of the plots when the temperature excursions were small. In these cases, a second 
straight line was drawn on these plots offset to $2 \%$ lower heat fluxes from the straight-line portion of the data curve. The start of film boiling was defined as the first data point at a higher heat flux than that at the intersection of the offset line and the curve through the data. Plots of this type are shown in Figures 9 and 10.

\section{Smooth Tube Data}

All of the data obtained with the smooth-wall flow tube and homogenizer inlet are shown in Figure 11, which is a plot of the average boiling burnout heat flux vs. outlet enthalpy for all flows investigated. It may be emphasized that the plotted heat flux is the average. In general, boiling burnout occurred on the inner 7 rods whose heat flux was $86.8 \%$ of the average.

Included on the plot are two nonburnout data points. These represent the maximum conditions of inlet enthalpy and heat flux that could be obtained at the flow rates of $2,000,000$ and $3,000,000 \mathrm{lb} / \mathrm{hr}-\mathrm{ft} \mathrm{t}^{2}$. Boiling burnout was not obtained at these conditions.

The data points for the fog inlet cases give smooth extensions of the points for subcooled inlet cases for the same flow rate. This indicates that there is nothing unique nor peculiar about the use of wet steam coolant, at least with the physical arrangement used in these tests. It may be pointed out that the 100 psid pressure drop across the valve in the steam line provided a stiff hydraulic supply system. This was done deliberately to reduce or eliminate the discrepancies between subcooled and fog-cooled data found in earlier tests which did not have the stiff supply characteristics. (I) 
The curves of Figure $I l$ are not particularly steep, indicating a rather weak dependency of boiling burnout on enthalpy of the bulk coolant. Furthermore, there is but a small separation between the curves for the four flow rates, indicating a somewhat unexpected weak dependence of boiling burnout on flow rate.

\section{Rough Tube Data}

All of the data obtained with the rough wall flow tube and homogem nizier inlet are shown in Figure 12, which is a plot of the average boiling burnout heat flux vs. outlet enthalpy. The data follow the same pattern as did those for the smooth wall tube.

Not shown in Figure 12 is that, in general, the temperature excursions following the start of bolling burnout when the rough tube wall was used were neither so abrupt nor as large as were those obtained when the smooth tube wall was used. A greater proportion of the rough wall boiling burnout points were defined by using the $2 \%$ offset method.

Also on Figure 12, the single fog inlet data point for each of the flow rates of $2,000,000$ and $3,000,000 \mathrm{lb} / \mathrm{hr}-\mathrm{ft}^{2}$ fell well above the extension of the lines through the subcooled inlet data points. The reason for this is not known, but is believed to be partly due to difficulty in defining boiling burnout. These two fog-inlet points and the highest enthalpy subcooled inlet data points for these flow rates had the least pronounced departure from the nonboiling burnout temperatures. Figure 9 is the temperature-heat flux plot for the condition of $3,000,000 \mathrm{lb} / \mathrm{hr}^{2} \mathrm{ft}^{2}$ and $1.8 \%$ inlet quality, and illustrates the type of 
behavior of these runs. The two high heat flux points plotted on Figure 12 may be due to the inability to closely define the start of boiling burnout in these cases.

\section{Effect of Concentrator}

Figures 13 and 14 show the effect of the concentrator for the cases of the smooth wall and rough wall tubes, respectively.

To recapitulate briefly, the inlet device to the test section opera ated either as a homogenizer or as a concentrator during fog inlet runs. When it functioned as a homogenizer, it provided a homogeneous two-phase stream to the inlet. When it functioned as a concentrator, it concentrated the liquid phase of the two phase mixture at the center of the flow tube and, therefore, placed most of the water on the heat transfer surfaces of the bundle. It was postulated that this preferential placement of the water would increase the boiling burnout heat fluxes.

Such was not the case, however. Figures 13 and 14 show no difference in the boiling burnout heat fluxes for the cases of homogeneous and concentrated fog inlets. Apparently, the beneficial effects of the preferred placing of the water were dissipated by the time the coolant had traveled the $23 \mathrm{l} / 2$ in. unheated length and $6.3 \mathrm{ft}$ heated length of the test section.

\section{Effect of Rough Wall}

Figures 15 through 18 show the effect of the rough tube wall on boiling burnout for each of the four flow rates investigated. Each figure shows plots of the boiling burnout heat flux vs. outlet enthalpy for both the smooth wall and the rough wall cases for a given flow rate. 
The rough wall did cause a significant increase in the boiling burnout heat flux. The increase varied from 10 to $35 \%$ for a given outlet enthalpy. The increase tended to be larger at the lowest and highest outlet enthalpies, and somewhat less at the intermediate outlet enthalpies. The increase also tended to be greater at the higher flow rates.

There are two mechanisms by which the rougheners are expected to increase boiling burnout heat fluxes. One applies only in the higher steam quality regions where annular flow is believed to exist. That is, the coolant flow consists of a film of liquid on the channel walls and a two-phase mixture of liquid droplets in a continuous vapor phase occupying the rest of the channel cross section. Boiling burnout occurs when the liquid film is removed from the heated surface. In these cases, the liquid film on the unheated walls of the channel is lost from effective cooling. Rougheners, such as were used in these tests, strip the liquid film from the unheated walls and place it into the bundle, where it is available to replenish the liquid film on the heated walls.

The other mechanism arises from the fact that there can be severe enthalpy imbalances in a bundle fuel element. (2) For this bundle, for example, if no cross-channel mixing is assumed, the enthalpy increase of the coolant in the small triangular flow passages next to the central rod will be approximately 2.6 times the average. Boiling burnout would be expected to take place in these high enthalpy regions. Any crosschannel mixing decreases the magnitude of the enthalpy imbalances and 
would be expected to increase the bolling burnout heat flux. The rougheners on the tube wall of these tests are believed to increase the cross-channel mixing.

Which of these two mechanisms is the more 1mportant is not known. Obviously, for the cases of high inlet subcooling where the bolling length is short and outlet quelities are low, the mixing mechanism is predominant. For the higher inlet enthalpy cases, either or both mechanisms may be effective.

It may be pointed out that rather severe roughening was used in these tests. The rougheners protruded $0.050 \mathrm{in}$. Into the $0.060 \mathrm{in}$. space between the bundle and the flow housing wall.

\section{Effect of Pressure}

The effect of pressure is shown in Figures 19 through 21 for the case of smooth pressure tube wall, homogenlzer inlet and subcooled inlet coolant. Two pressures were 1nvestigated, $1000 \mathrm{pgla}$ and $1200 \mathrm{pg} 1 \mathrm{a}$. The data show that the 1000 psia bolling burnout heat 1luxes were of the order of $10 \%$ higher than were those of the 1200 psla case.

\section{Iffect of Rod specing}

Flgures 19 through 21 also show the effect of rod apacing. The data from these tests are compared with data from 6.3 ft long, 19arod, electrically heated bundle that had 0.587 1n. OD rods, 0.050 in. spacins between rods, 0.100 1n. radial specing between rods and tube wall, and which used wire wraps to maintain rod spacing. (3)

The overlap of the $0.050 \mathrm{1n}$. spaced data and the $0.040 \mathrm{In}$. spaced data is not large. However, the plots on Figures 19 through 21 do show that the 0.050 1n. spaced bolling burnout heat fluxes curves are much 
steeper than those of the $0.040 \mathrm{in}$. spaced; i.e., the boiling burnout heat fluxes for the $0.050 \mathrm{in}$. spacing tend to be about the same as those for the $0.040 \mathrm{in.}$ spacing at the higher enthalpies, but greater than those of the $0.040 \mathrm{in.} \mathrm{spacing} \mathrm{at} \mathrm{the} \mathrm{intermediate} \mathrm{enthalpies.}$

The effect of rod spacing on boiling burnout is a complex matter about which little is known. This is particularly true of the bundes where the rods are arranged in a circular pattern as they are for this test section. In these cases, the flow distribution and heat generation distribution are such that very high local enthalpies can occur. The high local enthalpies are a function of not only the flow and heat generation distribution, but also the cross-channel mixing and the effect of local steam generation, if it occurs.

Previous tests have shown that reducing the rod spacing significantly reduces the boiling burnout heat flux. However, a study of these data concludes that the reduction is due to high local enthalpies, and that the boiling burnout heat flux actually increases with decreasing rod spacing, based on local enthalpy. (2)

The 0.040 in. spaced test section had a much smaller radial spacing between the test section and flow tube wall, 0.060 in., rather than 0.100 in. The reduction in the space between the test section and flow housing wall forced a larger fraction of the coolant flow into the interior of the bundle and thus should have reduced the extent of the high local enthalpies.

If it is assumed that no cross-channel mixing occurs, the small triangular channels next to the center rod have calculated enthalpy increases 2.6 times the bulk average. This may be compared with a similar value of 
2.9 for the 0.050 in. spaced bundie. Sunce the rod spacing and rod diam eters for the 0.050 in. and 0.040 ir spaced test sections are not greatly different, the crossmehannel mixing was expected to have been about the same for the two test sectins. Wherefore, the magnitude of the local high enthaipies for the 0.040 in spared test sections was expected to have beer less thar that of the 0.050 in spaced test secu tion and the burnout heat fluxes were expected to have been about the same or higher for the same conations.

It is not known why the roiling burnot heat fluxes for the 0.040 in spaced test section were lower. rine fact that they were points out that further experimentation concernire the effect of rod spacing on boting burnout and concerming the extent of nosscharrei mixing, both two phase and single phase, is required to permit optimum use of rod bunde fuel ejemerts.

Location of Boiling Burnout Boiling burncht aiways occured on the irrer? rods. For cases of Low enthalpy; boiling burnot ocoursd or hes oeten rad For cases of the higher outlet enthalpies, boining burnout cccurred on one and usually severail of the rods of the furod ran. 


\section{REFFERENCES}

(1) G. M. Hesson, D. E. Fitzsimmons, and J. M. Batch. Boiling Burnout Experiments with Fog-Cooled Nineteen-Rod Bundle Test Section. HW-80523. General Electric Company, Hanford Atomic Products Operation, January, 1964.

(2) J. G. Knudsen. The Effect of Mixing on Burnout in Multirod Bundles. HW-84525. December, 1964.

(3) E. D. Waters, G. M. Hesson, D. E. Fitzsimmons, and J. M. Batch. Boiling Burnout Experiments with 19-Rod Bundles in Axial Flow. HW-77303. August, 1963.

(4) J. M. Batch and G. M. Hesson. Comparison of Boiling Burnout Data for 19-Rod Bundle Fuel Elements Spaced with "Wires" and "Warts". HW-80391 REV 1. January, 1964.

(5) G. M. Hesson, D. E. Fitzsimmons, and J. M. Batch. Comparison of Boiling Burnout Data for 19-Rod Bundles in Horizontal and Vertical Positions. HW-83443 REV 1, July, 1964.

(6) J. M. Batch, K. G. Toyoda, and H. E. Hanthorn. The Thermal Hydraulics Laboratory at Hanford. HW-65722 REV. November, 1961. 


\section{TABLE I}

\section{Summary of Test Conditions}

\begin{tabular}{cllcc} 
Condition & $\begin{array}{c}\text { Iniet } \\
\text { Configuration }\end{array}$ & $\begin{array}{c}\text { Pressure } \\
\text { Tube Wall }\end{array}$ & $\begin{array}{c}\text { Inlet } \\
\text { Coolant } \\
\text { Condition }\end{array}$ & $\begin{array}{c}\text { Pressure } \\
\text { psia }\end{array}$ \\
\hline 1 & Homogenizer & Smooth & Subcooled & 1000 \\
2 & Homogenizer & Smooth & Subcoled & 1200 \\
3 & Homogenizer & Rough & Subcooled & 1.000 \\
4 & Homogenizer & Rough & Fog & 1000 \\
5 & Concentrator & Rough & Fog & 1000 \\
6 & Concentrator & Smooth & Fog & 1000 \\
7 & Homogenizer & Smooth & Fog & 1000 \\
\hline
\end{tabular}


TABLE II.

Experimental Results for the Conditions of Homogeneous Inlet, Smooth Pressure Tube Wall and 1000 psia Pressure

(Conditions 1 and $?$ of Table I)

\begin{tabular}{|c|c|c|c|c|c|c|c|c|c|}
\hline Numbe & $\begin{array}{c}\text { Mass Velocity } \\
\text { it } / \mathrm{hr}^{\mathrm{s}} \mathrm{ft}^{2} \\
\times \quad 10^{\mathrm{s}}\end{array}$ & $\begin{array}{c}\text { Iniet } \\
\text { Temper } \\
\text { ature } \\
\text { F }\end{array}$ & $\begin{array}{l}\text { Irlet } \\
\text { Quilty or } \\
\text { Subooling } \\
\text { \%or } \mathrm{E}\end{array}$ & $\begin{array}{l}\text { Inlet } \\
\text { Enthaipy } \\
\text { Etillit }\end{array}$ & $\begin{array}{c}\text { Power } \\
\mathrm{KW}\end{array}$ & $\begin{array}{c}\text { Errthalpy } \\
\text { Gain } \\
\text { Btu/lo } \\
\end{array}$ & $\begin{array}{c}\text { Furnoist esat } \\
\text { Fiux } \\
\text { Btu/hrofte } \\
\times 10^{6} \\
\end{array}$ & $\begin{array}{c}\text { Outlet } \\
\text { Entholiy } \\
\text { Btalle } \\
\end{array}$ & $\begin{array}{c}\text { Outiet } \\
\text { Quality or } \\
\text { Subcoling } \\
\text { o or } \mathrm{F}\end{array}$ \\
\hline 3 & I. 04 & 530 & $14^{5} \mathrm{~F}$ & 525 & 1550 & 289 & 0.292 & 814 & $41.9 \%$ \\
\hline 5 & $\therefore 05$ & 502 & $42 \%$ & 490 & 1650 & 287 & 0.293 & 776 & $360 \%$ \\
\hline 12 & .05 & $46 ?$ & $82^{\circ} \mathrm{F}$ & 444 & $i 800$ & 307 & 0.319 & 751 & 32.40 \\
\hline 3.3 & $=06$ & 423 & $121^{2} \mathrm{~F}$ & 400 & 1910 & 325 & 0.339 & 725 & $28 \quad 1 \%$ \\
\hline 20 & 107 & 345 & $200^{\circ}$ & 3.5 & 1970 & 336 & c 348 & 652 & $26.9 \%$ \\
\hline 21 & $\therefore=06$ & 248 & $295^{4}$ & 216 & 2200 & 375 & 0.390 & 591. & $7.3 \%$ \\
\hline 69 & 07 & & $18 \%$ & 657 & 170 & 211 & 0.207 & 868 & $50.2 \%$ \\
\hline 70 & $\therefore .01$ & & 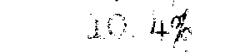 & 610 & 3310 & 237 & 0.233 & 847 & $1+6.9 \%$ \\
\hline $7 \mathrm{~B}$ & 1.01 & & $=5 x$ & $49 ?$ & .1390 & 232 & 0.246 & 829 & $44.2 \%$ \\
\hline 74 & 1.01 & $\cdots$ & $39.3 \%$ & 797 & 830 & 34 & 0.145 & 944 & $610 \%$ \\
\hline 2 & $\therefore 55$ & 538 & 19 & 928 & 1740 & 204 & 0.308 & 732 & $29 \quad 76$ \\
\hline 6 & $\therefore 52$ & 499 & 40 & $48 ?$ & 9900 & 220 & 0338 & 716 & $25.7 x$ \\
\hline 23 & $\therefore 53$ & $46=$ & $82^{5} F$ & 444 & 2100 & $24 \%$ & 0.372 & 693 & $232^{d}$ \\
\hline It & 7.55 & 424 & $i 20^{\circ} \mathrm{E}$ & 401 & 2240 & 26 & 0.395 & $56 ?$ & $18.5 \%$ \\
\hline 19 & 1.54 & 344 & $.99 \%$ & 36 & 2370 & 279 & 0.420 & 596 & 8.20 \\
\hline 22 & 1.55 & 320 & $23^{\circ} \mathrm{F}$ & 320 & $278 \mathrm{c}$ & 326 & 0.498 & 546 & $0.5 \%$ \\
\hline 3 & 200 & 536 & $8^{\circ} \mathrm{E}$ & 531 & 1910 & 173 & 0.339 & 704 & $24.9 \%$ \\
\hline 7 & I. 98 & 501 & $44^{\circ} \mathrm{F}$ & 488 & 2100 & 192 & 0.371 & 680 & $21.2 \%$ \\
\hline 10 & 202 & 450 & $82^{5} \mathrm{~F}$ & 444 & 2320 & 208 & 04.12 & 652 & $16.9 \%$ \\
\hline 15 & .99 & 425 & $119^{9} \mathrm{~F}$ & 402 & 2510 & 229 & 0.445 & 631 & $13 \% \%$ \\
\hline
\end{tabular}


TABLE II. (Continued)

\begin{tabular}{|c|c|c|c|c|c|c|c|c|c|}
\hline Number ${ }^{a}$ & $\begin{array}{c}\text { Mass Velocity } \\
\mathrm{lb} / \mathrm{hr}-\mathrm{ft} \mathrm{t}^{2} \\
\mathrm{x} 10^{-6}\end{array}$ & $\begin{array}{l}\text { Inlet } \\
\text { Temper- } \\
\text { ature } \\
{ }^{\circ} \mathrm{F} \\
\end{array}$ & $\begin{array}{l}\text { Inlet } \\
\text { Quality or } \\
\text { Subcooling } \\
\text { \% or }{ }^{\circ} \mathrm{F}\end{array}$ & $\begin{array}{l}\text { Inlet } \\
\text { Enthalpy } \\
\text { Btu/lb }\end{array}$ & $\begin{array}{c}\text { Power } \\
\mathrm{kW}\end{array}$ & $\begin{array}{c}\text { Enthalpy } \\
\text { Gain } \\
\text { Btu/lb }\end{array}$ & $\begin{array}{c}\text { Burnout Heat } \\
\text { Flux } \\
\text { Btu/hr-ft } \\
\times 10^{-6} \\
\end{array}$ & $\begin{array}{l}\text { Outlet } \\
\text { Enthalpy } \\
\text { Btu/lb }\end{array}$ & $\begin{array}{c}\text { Outlet } \\
\text { Quality or } \\
\text { Subcooling } \\
\text { \% or }{ }^{\circ} \mathrm{F}\end{array}$ \\
\hline $\begin{array}{l}18 \\
23 \\
72 \\
75^{*} c\end{array}$ & $\begin{array}{l}2.04 \\
2.02 \\
2.00 \\
2.01\end{array}$ & $\begin{array}{c}346 \\
248 \\
- \\
-\end{array}$ & $\begin{array}{l}198^{\circ} \mathrm{F} \\
296^{\circ} \mathrm{F} \\
5.3 \% \\
30.0 \%\end{array}$ & $\begin{array}{l}249 \\
217 \\
577 \\
737\end{array}$ & $\begin{array}{r}2790 \\
3310 \\
1800 \\
830\end{array}$ & $\begin{array}{r}317 \\
297 \\
164 \\
75\end{array}$ & $\begin{array}{l}0.494 \\
0.585 \\
0.319 \\
0.147\end{array}$ & $\begin{array}{l}566 \\
513 \\
741 \\
812\end{array}$ & $\begin{array}{l}3.6 \% \\
23.2^{\circ} \mathrm{F} \\
30.6 \% \\
41.6 \%\end{array}$ \\
\hline $\begin{array}{l}4 \\
8 \\
9 \\
16 \\
17 \\
73 \\
76 * c\end{array}$ & $\begin{array}{l}3.00 \\
3.00 \\
3.00 \\
2.98 \\
2.99 \\
3.00 \\
3.00\end{array}$ & $\begin{array}{l}534 \\
494 \\
460 \\
421 \\
346 \\
= \\
=\end{array}$ & $\begin{array}{c}10^{\circ} \mathrm{F} \\
50^{\circ} \mathrm{F} \\
85^{\circ} \mathrm{F} \\
123^{\circ} \mathrm{F} \\
198^{\circ} \mathrm{F} \\
2.3 \% \\
20.8 \%\end{array}$ & $\begin{array}{l}530 \\
481 \\
441 \\
398 \\
318 \\
558 \\
677\end{array}$ & $\begin{array}{r}2320 \\
2540 \\
2830 \\
3010 \\
3610 \\
2220 \\
820\end{array}$ & $\begin{array}{l}140 \\
154 \\
171 \\
184 \\
219 \\
134 \\
50\end{array}$ & $\begin{array}{l}0.410 \\
0.450 \\
0.500 \\
0.533 \\
0.639 \\
0.393 \\
0.145\end{array}$ & $\begin{array}{l}670 \\
635 \\
612 \\
582 \\
537 \\
692 \\
727\end{array}$ & $\begin{array}{c}19.6 \% \\
14.3 \% \\
10.8 \% \\
6.0 \% \\
4.0^{\circ} \mathrm{F} \\
23.0 \% \\
28.4 \%\end{array}$ \\
\hline
\end{tabular}

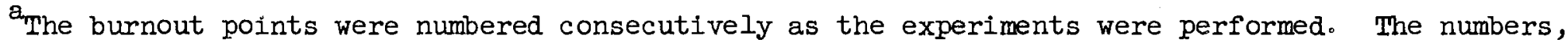
therefore, give the order of performance.

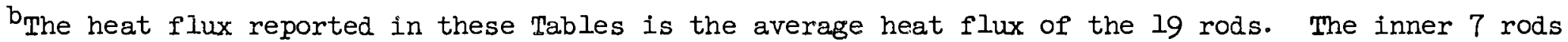
had a heat flux of 0.867 times the average heat flux.

${ }^{c}$ Those runs marked with an asterisk did not reach boiling burnout. They are at the maximum conditions that could be reached with the equipment. 


\section{TABLE III.}

Experimental Results for the Conditions of Homogeneous Inlet, Rough Pressure Tube Wall and 1000 psia Pressure

(Conditions 3 and 4 of Table I)

\begin{tabular}{|c|c|c|c|c|c|c|c|c|c|}
\hline Number ${ }^{\mathrm{a}}$ & $\begin{array}{c}\text { Mass Velocity } \\
\begin{array}{c}\mathrm{lb} / \mathrm{hr}-\mathrm{ft} \\
\times 10^{-6}\end{array} \\
\end{array}$ & $\begin{array}{l}\text { Inlet } \\
\text { Temper- } \\
\text { ature } \\
{ }^{\circ} \mathrm{F} \\
\end{array}$ & $\begin{array}{c}\text { Inlet } \\
\text { Quality or } \\
\text { Subcooling } \\
\phi \text { or }^{\circ} \mathrm{F} \\
\end{array}$ & $\begin{array}{c}\text { Inlet } \\
\text { Enthalpy } \\
\text { Btu/lb }\end{array}$ & $\begin{array}{c}\text { Power } \\
\mathrm{kW} \\
\end{array}$ & $\begin{array}{c}\text { Enthalpy } \\
\text { Gain } \\
\text { Btu/lb } \\
\end{array}$ & $\begin{array}{c}\text { Burnout Heat } \\
\text { Flux } \\
\text { Btu/hr-ft } \\
\times 10^{-6} \\
\end{array}$ & $\begin{array}{l}\text { Outlet } \\
\text { Enthalpy } \\
\text { Btu/lb }\end{array}$ & $\begin{array}{c}\text { Outlet } \\
\text { Quality or } \\
\text { Subcooling } \\
\text { \% or }{ }^{\circ} \mathrm{F} \\
\end{array}$ \\
\hline $\begin{array}{l}33 \\
40 \\
41 \\
47 \\
49 \\
53 \\
54 \\
55 \\
56\end{array}$ & $\begin{array}{l}1.05 \\
1.06 \\
1.08 \\
1.04 \\
1.04 \\
1.09 \\
1.04 \\
1.04 \\
1.04\end{array}$ & $\begin{array}{l}539 \\
500 \\
462 \\
421 \\
342 \\
246 \\
- \\
- \\
-\end{array}$ & $\begin{array}{c}5^{\circ} \mathrm{F} \\
44^{\circ} \mathrm{F} \\
82^{\circ} \mathrm{F} \\
123^{\circ} \mathrm{F} \\
202^{\circ} \mathrm{F} \\
298^{\circ} \mathrm{F} \\
19 \%^{\circ} \\
8.2 \% \\
2.6 \%\end{array}$ & $\begin{array}{l}535 \\
488 \\
443 \\
398 \\
313 \\
214 \\
666 \\
591 \\
559\end{array}$ & $\begin{array}{l}1670 \\
1830 \\
1960 \\
1980 \\
2270 \\
2680 \\
1380 \\
1540 \\
1620\end{array}$ & $\begin{array}{l}289 \\
315 \\
330 \\
346 \\
395 \\
446 \\
241 \\
268 \\
282\end{array}$ & $\begin{array}{l}0.296 \\
0.324 \\
0.347 \\
0.351 \\
0.402 \\
0.474 \\
0.245 \\
0.273 \\
0.288\end{array}$ & $\begin{array}{l}824 \\
803 \\
773 \\
744 \\
708 \\
661 \\
906 \\
858 \\
841\end{array}$ & $\begin{array}{l}43.4 \% \\
40.1 \% \\
35.6 \% \\
31.0 \% \\
25.5 \% \\
18.2 \% \\
56.0 \% \\
48.6 \% \\
46.0 \%\end{array}$ \\
\hline $\begin{array}{l}34 \\
39 \\
42 \\
48 \\
50 \\
52\end{array}$ & $\begin{array}{l}1.54 \\
1.54 \\
1.56 \\
1.50 \\
1.50 \\
1.54\end{array}$ & $\begin{array}{l}537 \\
500 \\
463 \\
422 \\
344 \\
245\end{array}$ & $\begin{array}{r}7^{\circ} \mathrm{F} \\
44^{\circ} \mathrm{F} \\
81^{\circ} \mathrm{F} \\
122^{\circ} \mathrm{F} \\
200^{\circ} \mathrm{F} \\
299^{\circ} \mathrm{F}\end{array}$ & $\begin{array}{l}533 \\
488 \\
445 \\
399 \\
315 \\
213\end{array}$ & $\begin{array}{l}1980 \\
2170 \\
2260 \\
2380 \\
2740 \\
3360\end{array}$ & $\begin{array}{l}234 \\
256 \\
264 \\
288 \\
332 \\
395\end{array}$ & $\begin{array}{l}0.351 \\
0.384 \\
0.401 \\
0.421 \\
0.484 \\
0.594\end{array}$ & $\begin{array}{l}767 \\
744 \\
709 \\
687 \\
647 \\
608\end{array}$ & $\begin{array}{l}34.6 \% \\
31.0 \% \\
25.7 \% \\
22.2 \% \\
16.1 \% \\
10.1 \%\end{array}$ \\
\hline $\begin{array}{l}35 \\
38 \\
43\end{array}$ & $\begin{array}{l}1.99 \\
2.00 \\
2.00\end{array}$ & $\begin{array}{l}539 \\
499 \\
459\end{array}$ & $\begin{array}{r}5^{\circ} \mathrm{F} \\
46^{\circ} \mathrm{F} \\
85^{\circ} \mathrm{F}\end{array}$ & $\begin{array}{l}536 \\
486 \\
441\end{array}$ & $\begin{array}{l}2270 \\
2470 \\
2570\end{array}$ & $\begin{array}{l}206 \\
224 \\
233\end{array}$ & $\begin{array}{l}0.402 \\
0.437 \\
0.454\end{array}$ & $\begin{array}{l}742 \\
710 \\
674\end{array}$ & $\begin{array}{l}30.7 \% \\
25.9 \% \\
20.2 \%\end{array}$ \\
\hline
\end{tabular}


TABLE III. (Continued)

\begin{tabular}{|c|c|c|c|c|c|c|c|c|c|}
\hline Number ${ }^{a}$ & $\begin{array}{c}\text { Mass Velocity } \\
\begin{array}{l}1 \mathrm{~b} / \mathrm{hr}-\mathrm{ft}^{2} \\
\mathrm{x} 10^{-6}\end{array} \\
\end{array}$ & $\begin{array}{l}\text { Inlet } \\
\text { Temper- } \\
\text { ature } \\
{ }^{\circ} \mathrm{F} \\
\end{array}$ & $\begin{array}{c}\text { Inlet } \\
\text { Quality or } \\
\text { Subcooling } \\
\% \text { or }{ }^{\circ} \mathrm{F}\end{array}$ & $\begin{array}{l}\text { Inlet } \\
\text { Enthalpy } \\
\text { Btu/lb } \\
\end{array}$ & $\begin{array}{c}\text { Power } \\
\mathrm{kW}\end{array}$ & $\begin{array}{c}\text { Enthalpy } \\
\text { Gain } \\
\text { Btu/lb } \\
\end{array}$ & $\begin{array}{c}\text { Burnout Heat } \\
\text { Flux b } \\
\text { Btu/hr-ft }{ }^{2} \\
\times 10^{-6} \\
\end{array}$ & $\begin{array}{c}\text { Outlet } \\
\text { Enthalpy } \\
\text { Btu/lb } \\
\end{array}$ & $\begin{array}{c}\text { Outlet } \\
\text { Quality or } \\
\text { Subcooling } \\
\% \text { or }{ }^{\circ} \mathrm{F} \\
\end{array}$ \\
\hline $\begin{array}{l}46 \\
51 \\
57\end{array}$ & $\begin{array}{l}2.00 \\
2.03 \\
2.02\end{array}$ & $\begin{array}{c}422 \\
345 \\
-\end{array}$ & $\begin{array}{l}123^{\circ} \mathrm{F} \\
199^{\circ} \mathrm{F} \\
4.7 \%\end{array}$ & $\begin{array}{l}398 \\
317 \\
573\end{array}$ & $\begin{array}{l}2810 \\
3300 \\
2410\end{array}$ & $\begin{array}{l}255 \\
295 \\
217\end{array}$ & $\begin{array}{l}0.497 \\
0.584 \\
0.427\end{array}$ & $\begin{array}{l}654 \\
612 \\
790\end{array}$ & $\begin{array}{l}17.1 \% \\
10.6 \% \\
38.1 \%\end{array}$ \\
\hline $\begin{array}{l}36 \\
37 \\
44 \\
45 \\
58\end{array}$ & $\begin{array}{l}3.02 \\
3.03 \\
2.93 \\
2.97 \\
3.02\end{array}$ & $\begin{array}{l}538 \\
500 \\
464 \\
427 \\
-\end{array}$ & $\begin{array}{r}6^{\circ} \mathrm{F} \\
44^{\circ} \mathrm{F} \\
80^{\circ} \mathrm{F} \\
117^{\circ} \mathrm{F} \\
1.8 \%\end{array}$ & $\begin{array}{l}535 \\
488 \\
446 \\
404 \\
554\end{array}$ & $\begin{array}{l}2880 \\
3110 \\
3230 \\
3560 \\
3000\end{array}$ & $\begin{array}{l}173 \\
186 \\
200 \\
218 \\
180\end{array}$ & $\begin{array}{l}0.510 \\
0.551 \\
0.571 \\
0.630 \\
0.530\end{array}$ & $\begin{array}{l}708 \\
674 \\
646 \\
622 \\
734\end{array}$ & $\begin{array}{l}25.5 \% \\
20.3 \% \\
16.0 \% \\
12.2 \% \\
29.4 \%\end{array}$ \\
\hline
\end{tabular}

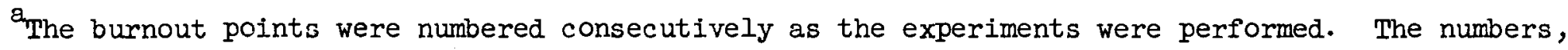
therefore, give the order of performance.

$b_{\text {The heat }}$ flux reported in these Tables is the average heat flux of the 19 rods. The inner 7 rods had a heat flux of 0.867 times the average heat flux. 


\section{TABLE IV。}

Experimental Results for the Conditions of Homogeneous Inlet, Smooth

Pressure Tube Wall and 1200 psia Pressure

(Condition 2 of Table I)

\begin{tabular}{|c|c|c|c|c|c|c|c|c|c|}
\hline Number ${ }^{a}$ & $\begin{array}{c}\text { Mass Velocity } \\
1 \mathrm{~b} / \mathrm{hr}^{-}=\mathrm{ft}^{2} \\
\times 10^{-6}\end{array}$ & $\begin{array}{c}\text { Inlet } \\
\text { Temper- } \\
\text { ature } \\
{ }^{\circ} \mathrm{F} \\
\end{array}$ & $\begin{array}{c}\text { Inlet } \\
\text { Quality or } \\
\text { Subcooling } \\
\% \text { or }{ }^{\circ} \mathrm{F}\end{array}$ & $\begin{array}{c}\text { Inlet } \\
\text { Enthalpy } \\
\text { Btu/lb } \\
\end{array}$ & $\begin{array}{c}\text { Power } \\
\mathrm{kW}\end{array}$ & $\begin{array}{c}\text { Enthalpy } \\
\text { Gain } \\
\text { Btu/lb } \\
\end{array}$ & $\begin{array}{l}\text { Burnout Heat } \\
\text { Flux } \\
\text { Btu/hr-ft } \\
\times 1 t^{2} \\
\end{array}$ & $\begin{array}{l}\text { Outlet } \\
\text { Enthalpy } \\
\text { Btu/lb }\end{array}$ & $\begin{array}{l}\text { Outlet } \\
\text { Quality or } \\
\text { Subcooling } \\
\text { \% or }{ }^{\circ} \mathrm{F}\end{array}$ \\
\hline $\begin{array}{l}30 \\
26 \\
25\end{array}$ & $\begin{array}{l}1.05 \\
1.05 \\
1.06\end{array}$ & $\begin{array}{l}538 \\
346 \\
246\end{array}$ & $\begin{array}{r}33^{\circ} \mathrm{F} \\
221^{\circ} \mathrm{F} \\
322^{\circ} \mathrm{F}\end{array}$ & $\begin{array}{l}534 \\
318 \\
214\end{array}$ & $\begin{array}{l}1420 \\
1780 \\
2080\end{array}$ & $\begin{array}{l}246 \\
307 \\
357\end{array}$ & $\begin{array}{l}0.252 \\
0.315 \\
0.364\end{array}$ & $\begin{array}{l}780 \\
625 \\
571\end{array}$ & $\begin{array}{l}34.1 \% \\
8.7 \%^{\circ} \\
0.6^{\circ} \mathrm{F}\end{array}$ \\
\hline $\begin{array}{l}29 \\
31 \\
27 \\
24\end{array}$ & $\begin{array}{l}2.04 \\
2.04 \\
2.03 \\
2.05\end{array}$ & $\begin{array}{l}538 \\
503 \\
345 \\
247\end{array}$ & $\begin{array}{r}29^{\circ} \mathrm{F} \\
64^{\circ} \mathrm{F} \\
222^{\circ} \mathrm{F} \\
320^{\circ} \mathrm{F}\end{array}$ & $\begin{array}{l}534 \\
491 \\
317 \\
216\end{array}$ & $\begin{array}{l}1800 \\
1930 \\
2750 \\
3020\end{array}$ & $\begin{array}{l}161 \\
172 \\
246 \\
278\end{array}$ & $\begin{array}{l}0.319 \\
0.342 \\
0.487 \\
0.554\end{array}$ & $\begin{array}{l}695 \\
663 \\
563 \\
493\end{array}$ & $\begin{array}{r}29.4 \% \\
14.9 \% \\
6.4^{\circ} \mathrm{F} \\
62.8^{\circ} \mathrm{F}\end{array}$ \\
\hline $\begin{array}{l}28 \\
32\end{array}$ & $\begin{array}{l}3.02 \\
3.03\end{array}$ & $\begin{array}{l}539 \\
502\end{array}$ & $\begin{array}{l}28^{\circ} \mathrm{F} \\
66^{\circ} \mathrm{F}\end{array}$ & $\begin{array}{l}535 \\
490\end{array}$ & $\begin{array}{l}2260 \\
2370\end{array}$ & $\begin{array}{l}136 \\
142\end{array}$ & $\begin{array}{l}0.401 \\
0.419\end{array}$ & $\begin{array}{l}671 \\
632\end{array}$ & $\begin{array}{r}16.2 \% \\
9.8 \%\end{array}$ \\
\hline
\end{tabular}

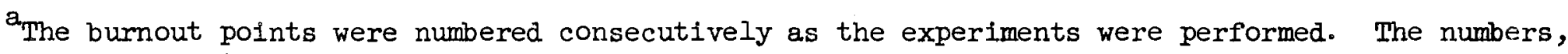
therefore, give the order of performance.

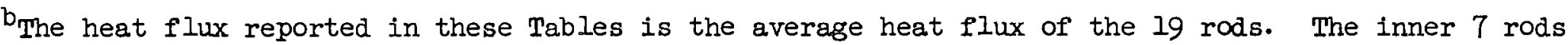
had a heat flux of 0.867 times the average heat flux. 


\section{TABLE V.}

Experimental Results for the Conditions of Concentrated Inlet, Rough and Smooth Pressure Tube Wall and 1000 psia Pressure

(Conditions 5 and 6 of Table I)

\begin{tabular}{|c|c|c|c|c|c|c|c|c|c|}
\hline Number ${ }^{a}$ & $\begin{array}{c}\text { Mass Velocity } \\
\text { Ib/hr-ft } \\
x 10^{-6} \\
\end{array}$ & $\begin{array}{c}\text { Inlet } \\
\text { Quality } \\
\%\end{array}$ & $\begin{array}{l}\text { Inlet } \\
\text { Enthalpy } \\
\text { Btu/lb }\end{array}$ & $\begin{array}{c}\text { Power } \\
\mathrm{kW}\end{array}$ & $\begin{array}{l}\text { Enthalpy } \\
\text { Gain } \\
\text { Btu/lb }\end{array}$ & $\begin{array}{c}\text { Burnout Heat } \\
\text { Flux } \\
\text { Btu/hr-ft } t^{2} \\
\times 10^{-6}\end{array}$ & $\begin{array}{c}\text { Outlet } \\
\text { Enthalpy } \\
\text { Btu/lb }\end{array}$ & $\begin{array}{c}\text { Outlet } \\
\text { Quality } \\
\text { of }\end{array}$ & Tube Wall \\
\hline $\begin{array}{l}59 \\
60 \\
61 \\
62 \\
63\end{array}$ & $\begin{array}{l}1.03 \\
1.03 \\
1.03 \\
2.04 \\
3.03\end{array}$ & $\begin{array}{r}17.2 \\
9.5 \\
5.4 \\
5.4 \\
2.5\end{array}$ & $\begin{array}{l}654 \\
604 \\
578 \\
578 \\
559\end{array}$ & $\begin{array}{l}1470 \\
1540 \\
1630 \\
2270 \\
3100\end{array}$ & $\begin{array}{l}257 \\
272 \\
287 \\
202 \\
176\end{array}$ & $\begin{array}{l}0.260 \\
0.273 \\
0.288 \\
0.401 \\
0.550\end{array}$ & $\begin{array}{l}911 \\
876 \\
864 \\
779 \\
735\end{array}$ & $\begin{array}{l}56.8 \\
51.4 \\
49.6 \\
36.5 \\
29.6\end{array}$ & $\begin{array}{c}\text { Rough } \\
\text { "" } \\
" \\
\text { Rough }\end{array}$ \\
\hline $\begin{array}{l}64 \\
65 \\
66 \\
67 \\
68\end{array}$ & $\begin{array}{l}1.01 \\
1.01 \\
1.01 \\
2.01 \\
3.02\end{array}$ & $\begin{array}{r}17.9 \\
10.3 \\
5.3 \\
5.3 \\
2.3\end{array}$ & $\begin{array}{l}658 \\
609 \\
577 \\
577 \\
558\end{array}$ & $\begin{array}{l}1160 \\
1370 \\
1380 \\
1750 \\
2260\end{array}$ & $\begin{array}{l}208 \\
246 \\
246 \\
158 \\
135\end{array}$ & $\begin{array}{l}0.205 \\
0.243 \\
0.245 \\
0.310 \\
0.400\end{array}$ & $\begin{array}{l}866 \\
854 \\
823 \\
735 \\
693\end{array}$ & $\begin{array}{l}49.8 \\
48.1 \\
43.2 \\
29.7 \\
23.2\end{array}$ & $\begin{array}{l}\text { Smooth } \\
n \\
n \\
" \\
\text { Smooth }\end{array}$ \\
\hline
\end{tabular}

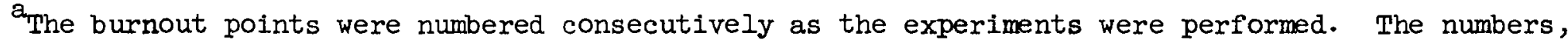
therefore, give the order of performance.

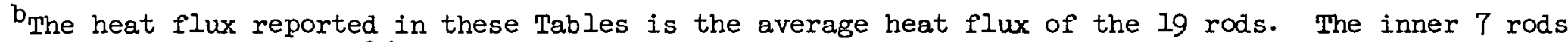
had a heat flux of 0.867 times the average heat flux. 


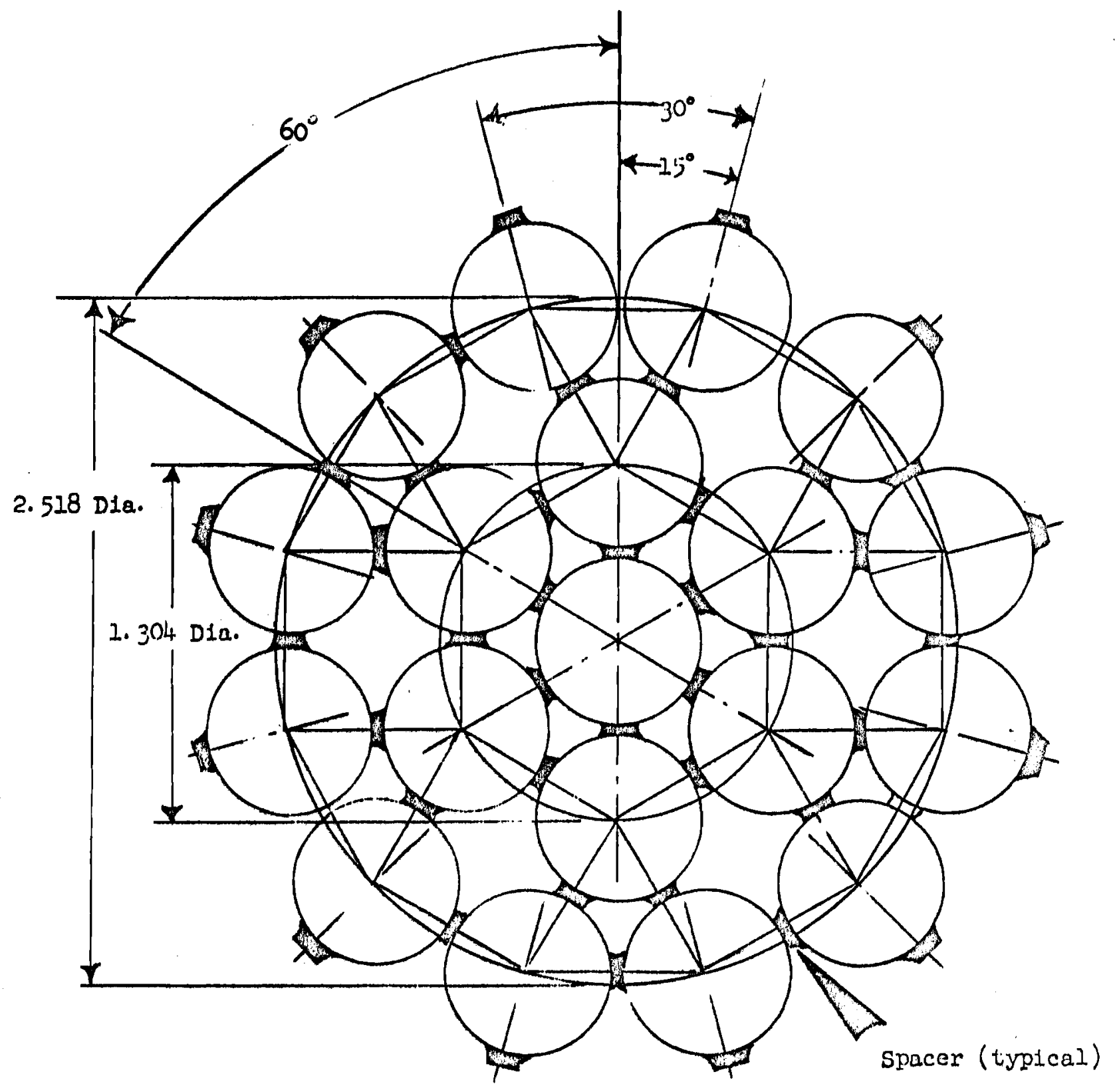

Figure l. 


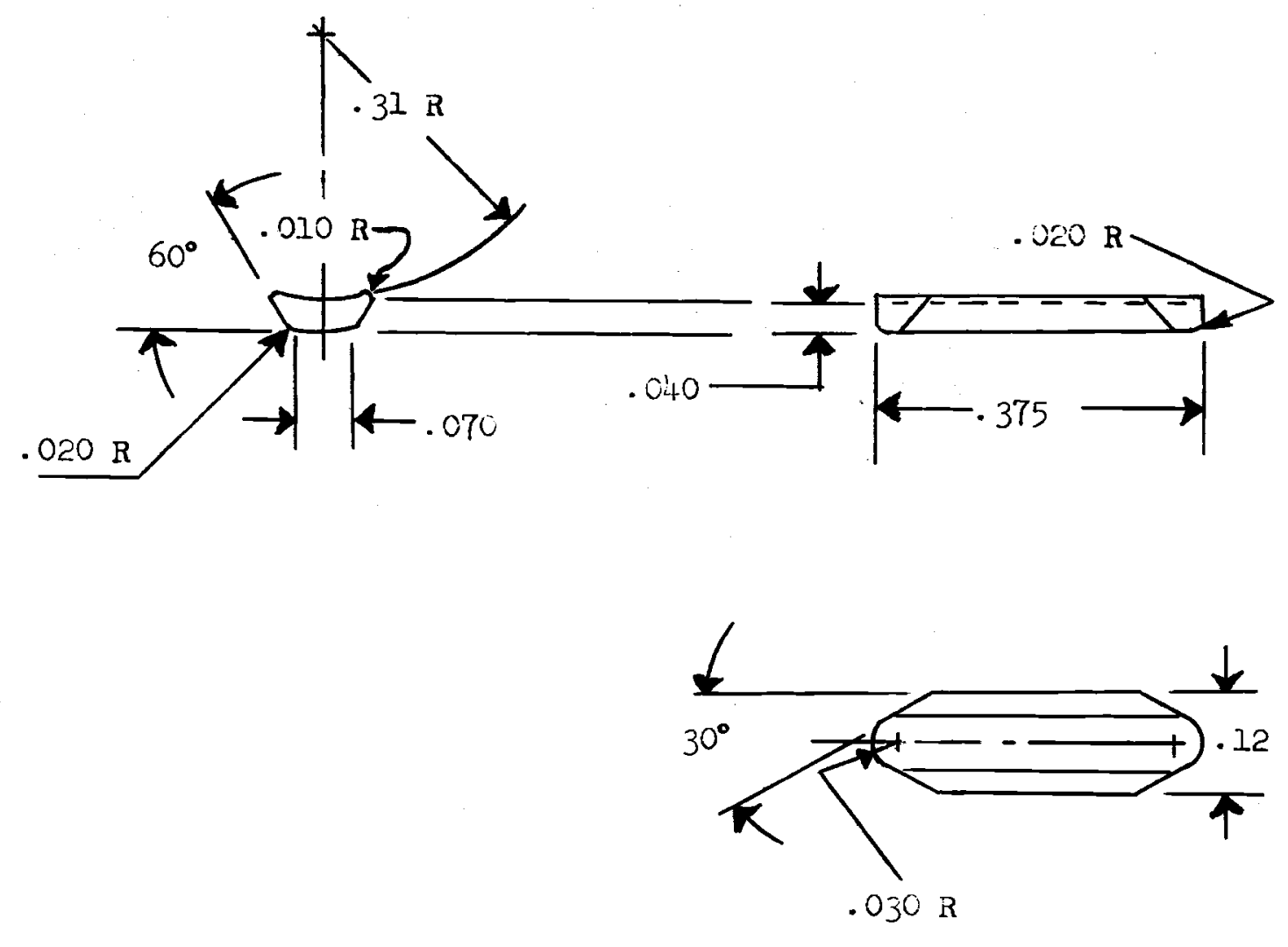

Figure 2A.

Details of the Warts used to Maintain Spccing Between Rods 

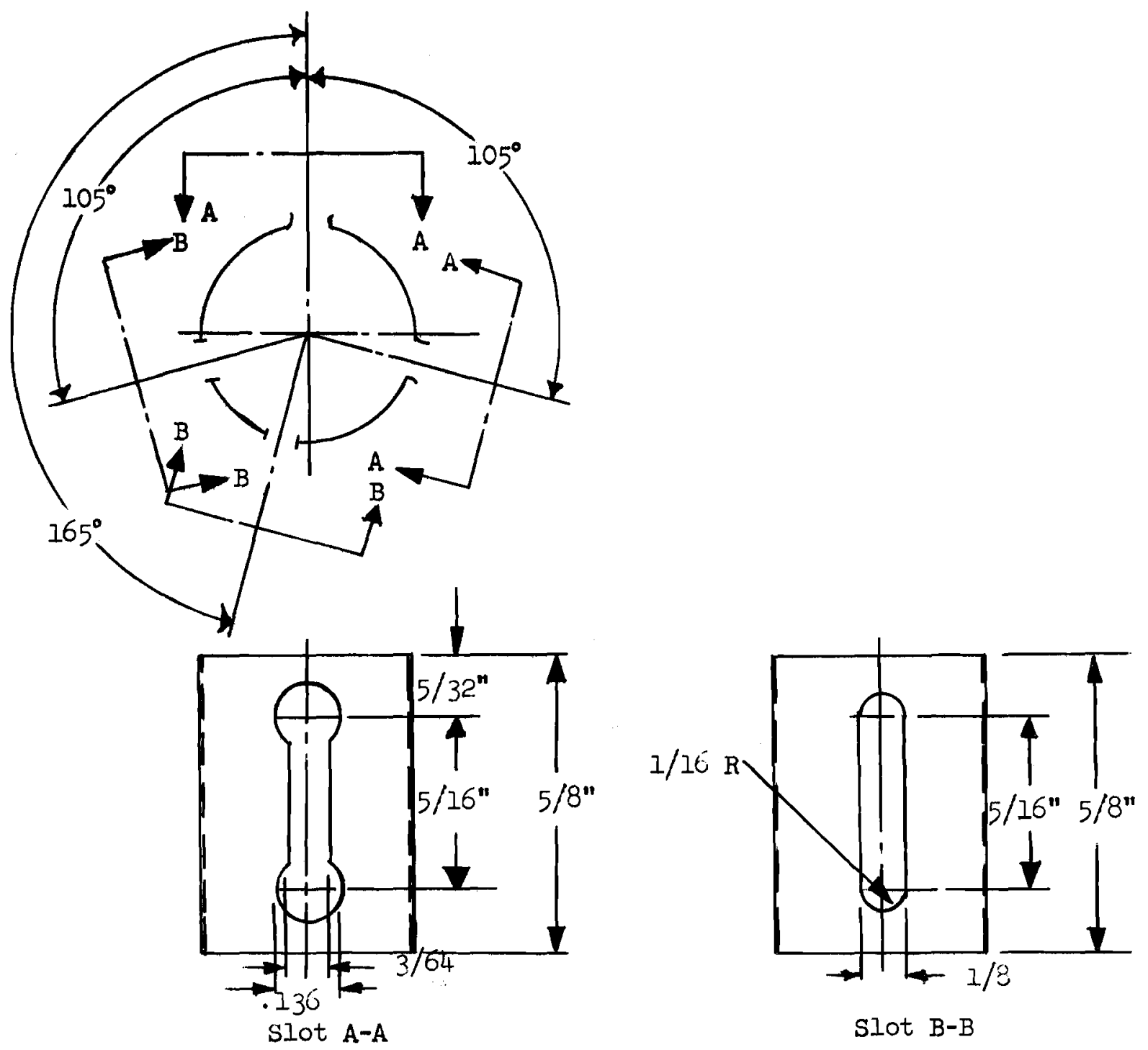

Figure 2B.

Details of the Ferrules used to Attach the Wart Spacers to the Heated Rods 


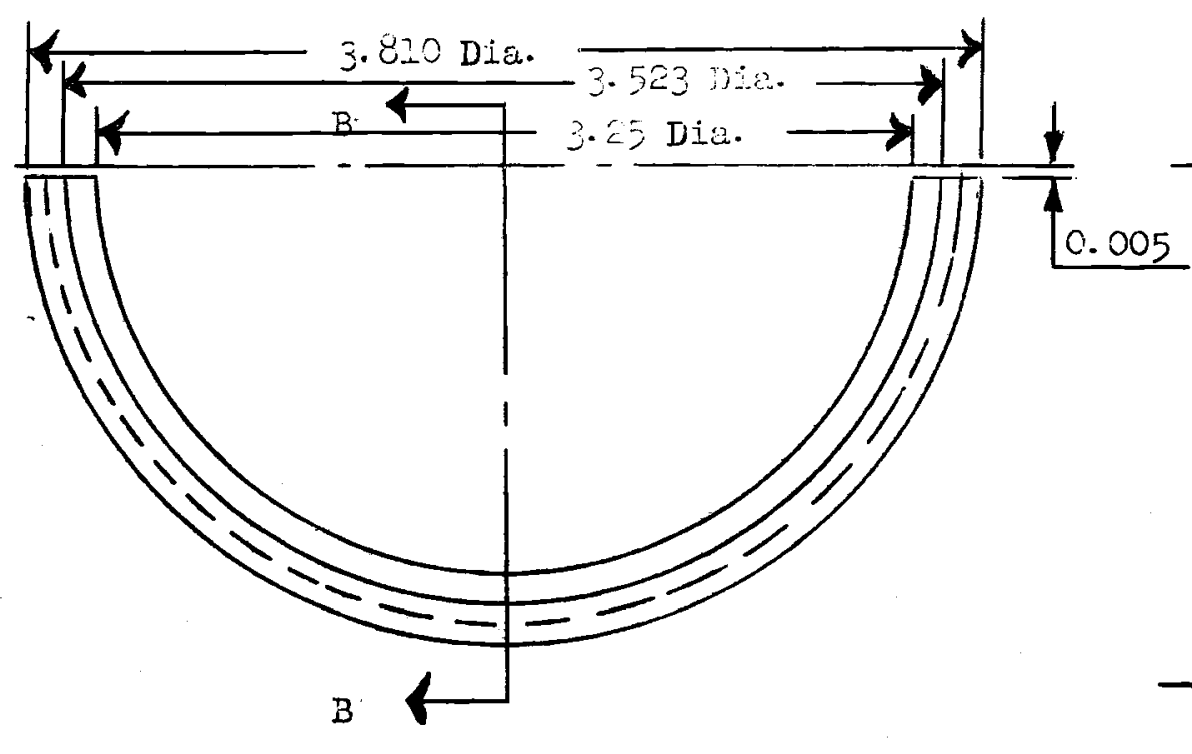

Cexaria Tube Liner
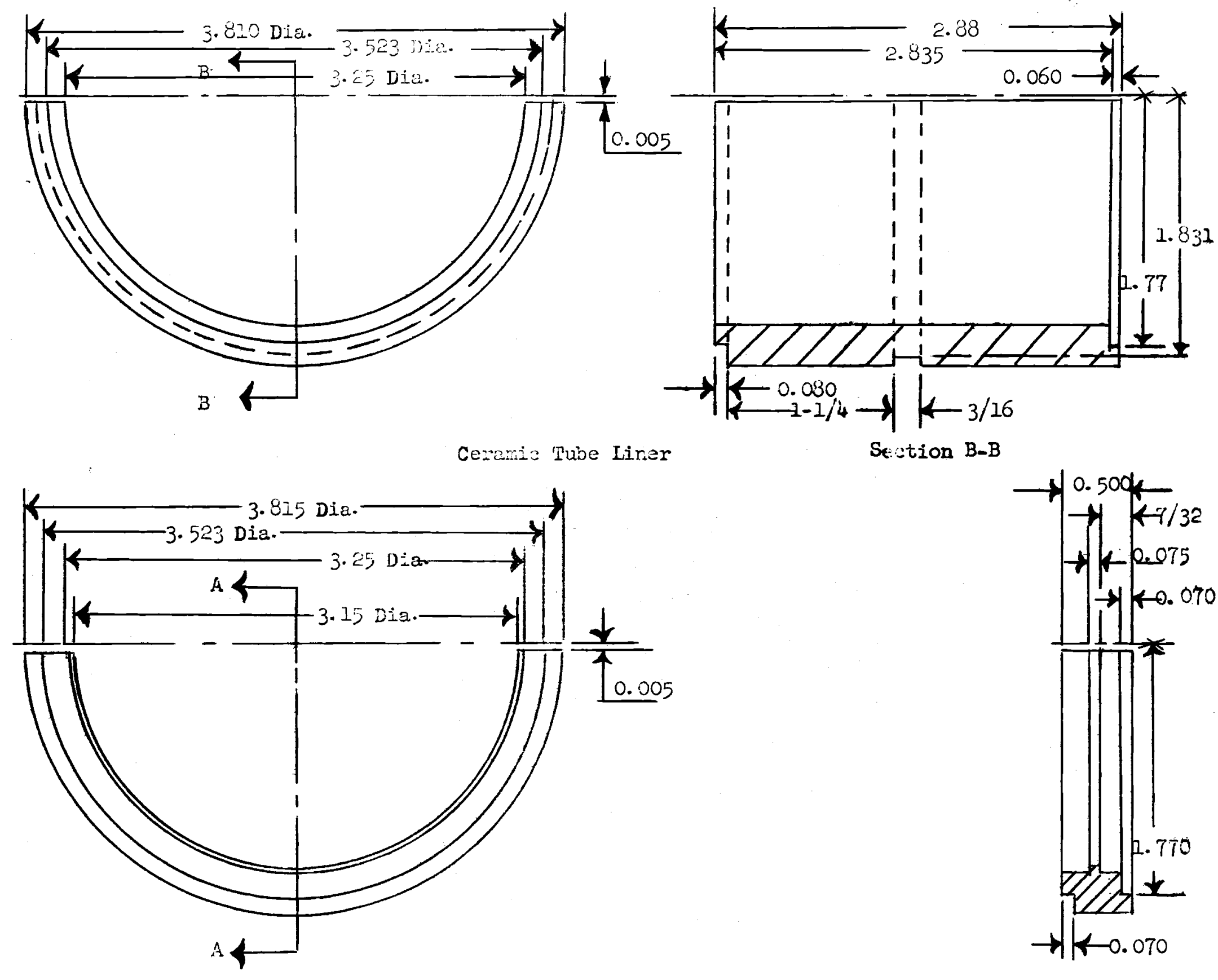

Ceraxic Ridge

Section A-A 
Thermocouple Plug
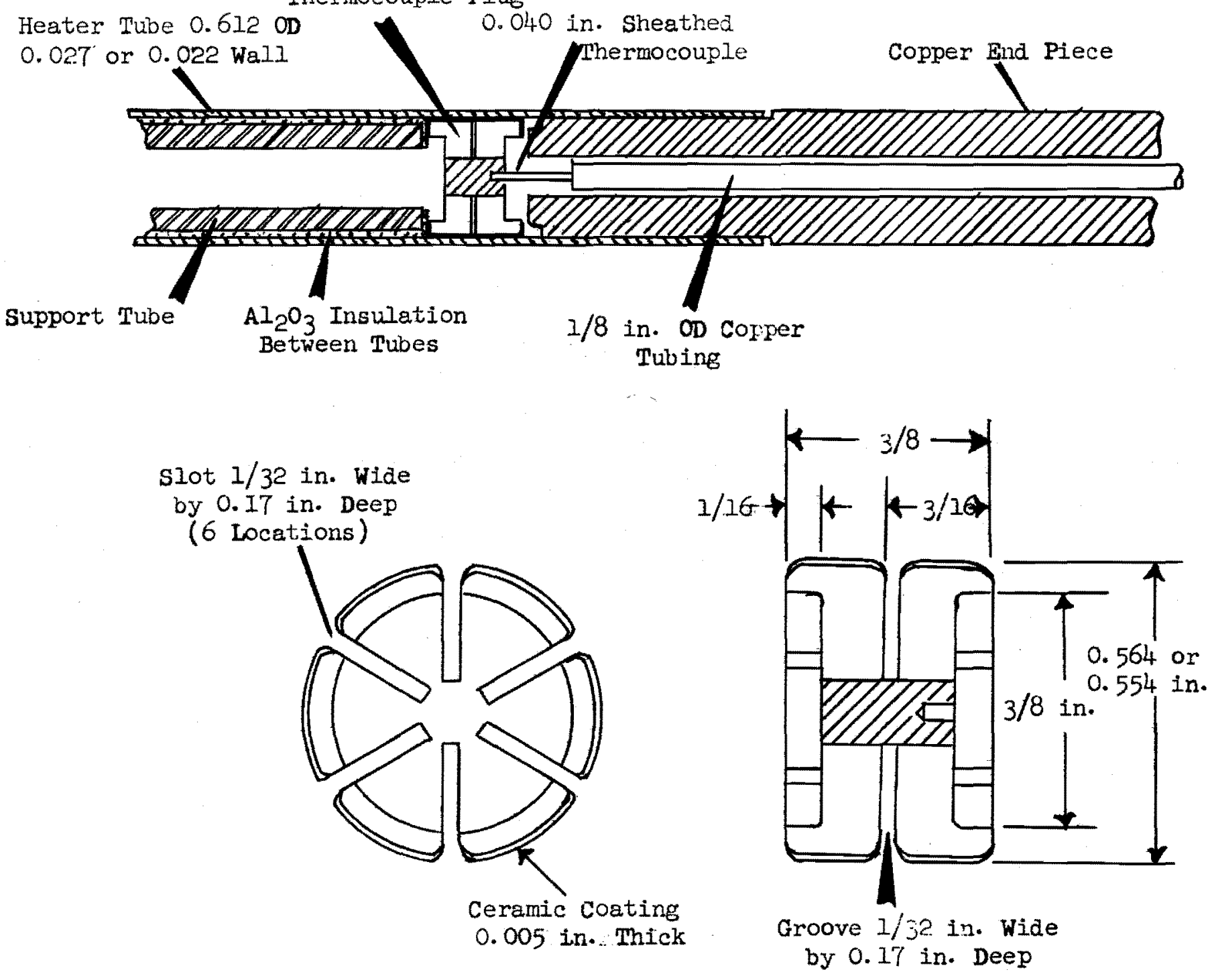

Figure 4.

Details of the Thermocouple Plug and Thermocouple Installation 


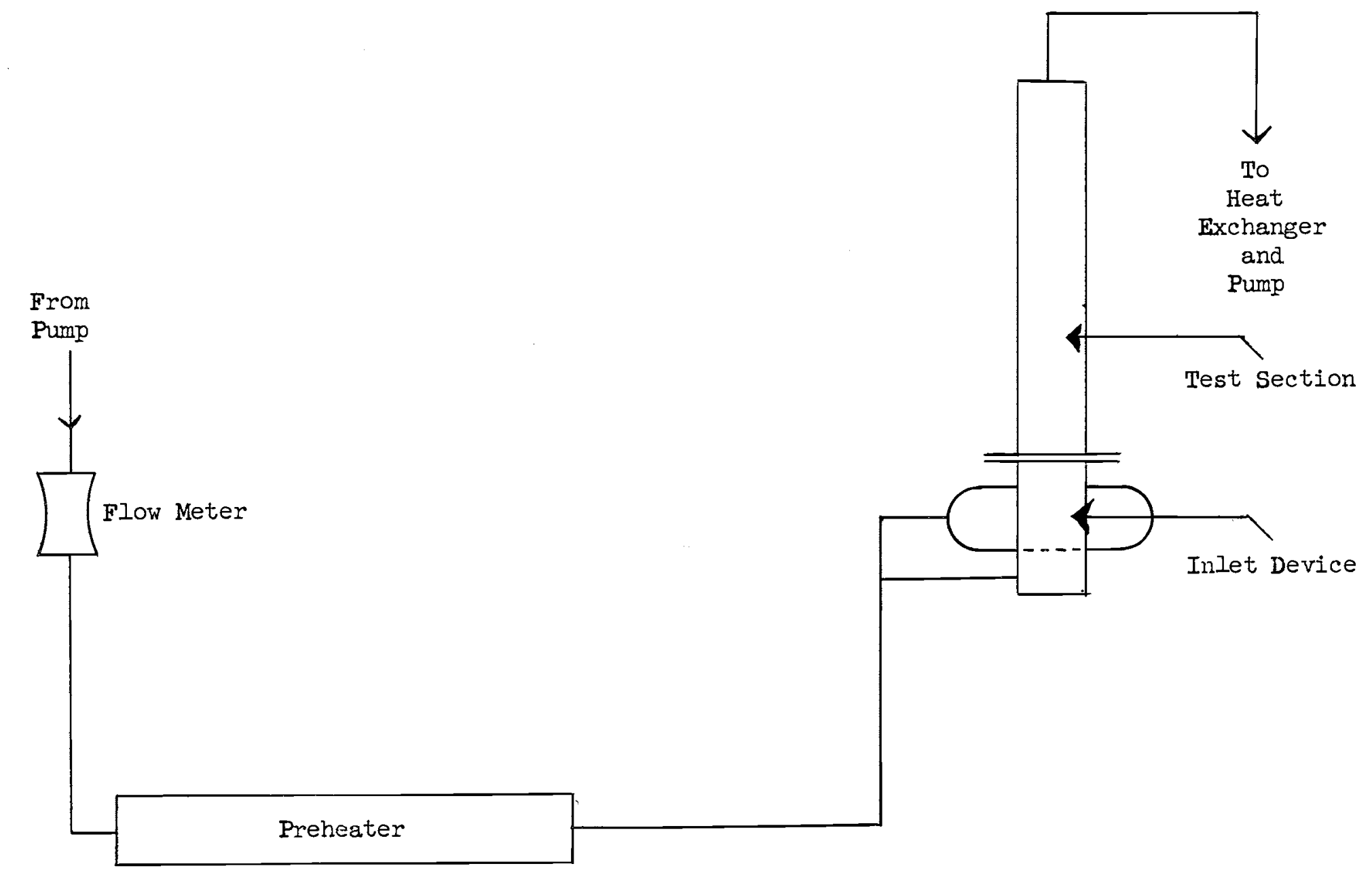

Figure 5.

Schematic Diagram of Piping Arrangement for the Subcooled Runs 


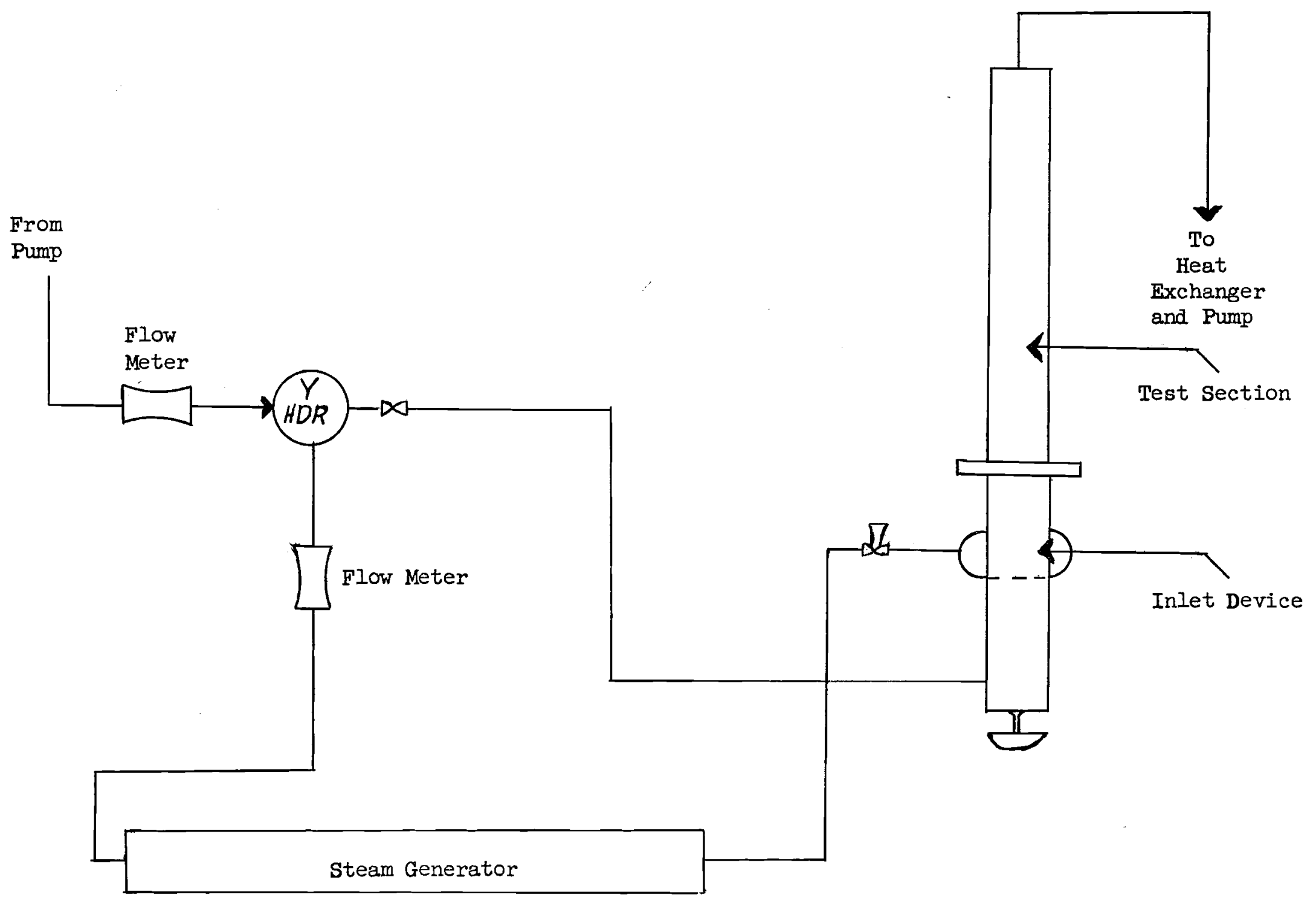

Figure 6. 


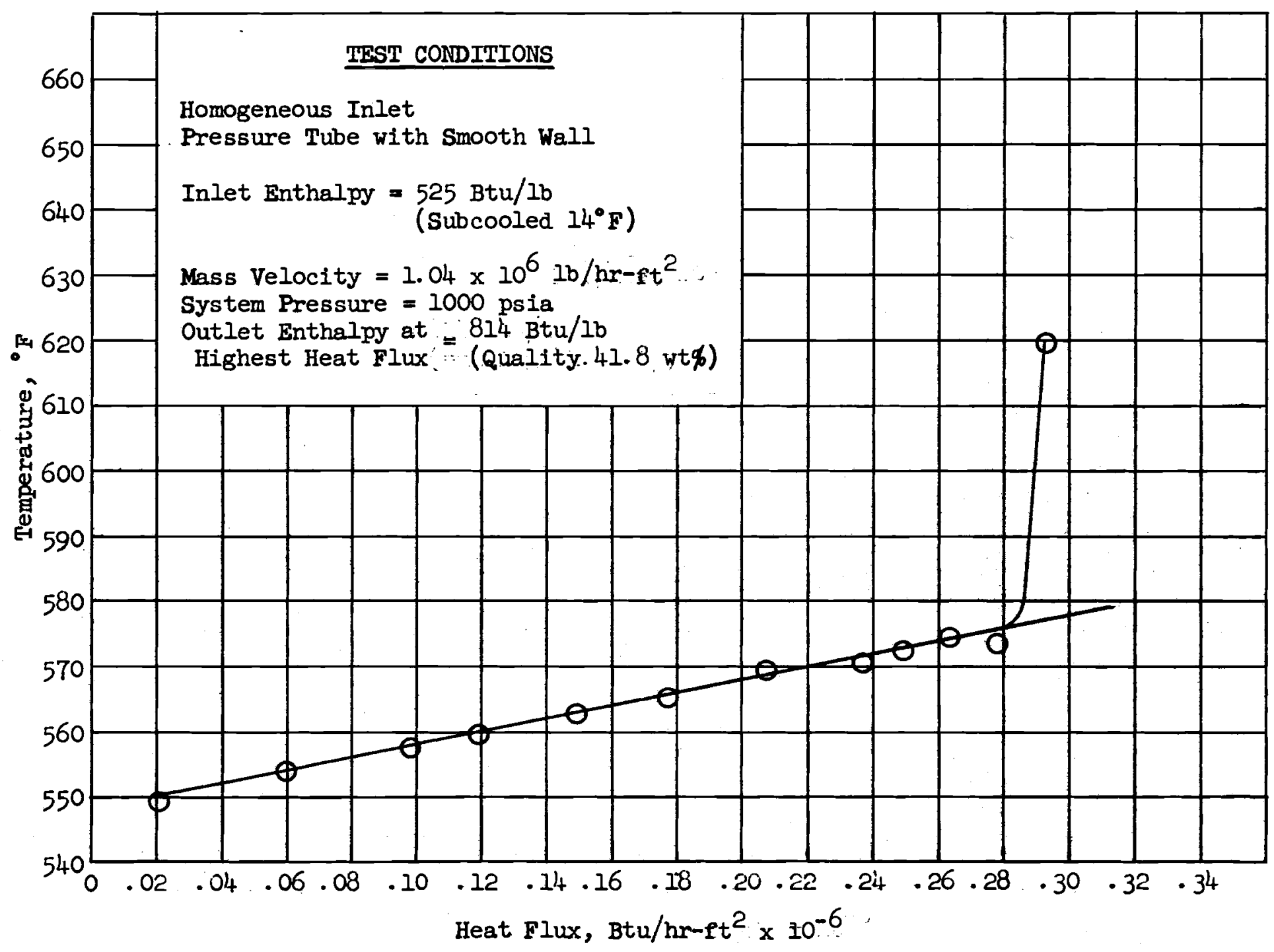

Figure 7 .

Typical Rod Temperature Behavior Where a Large Sudden Excursion Occurred 


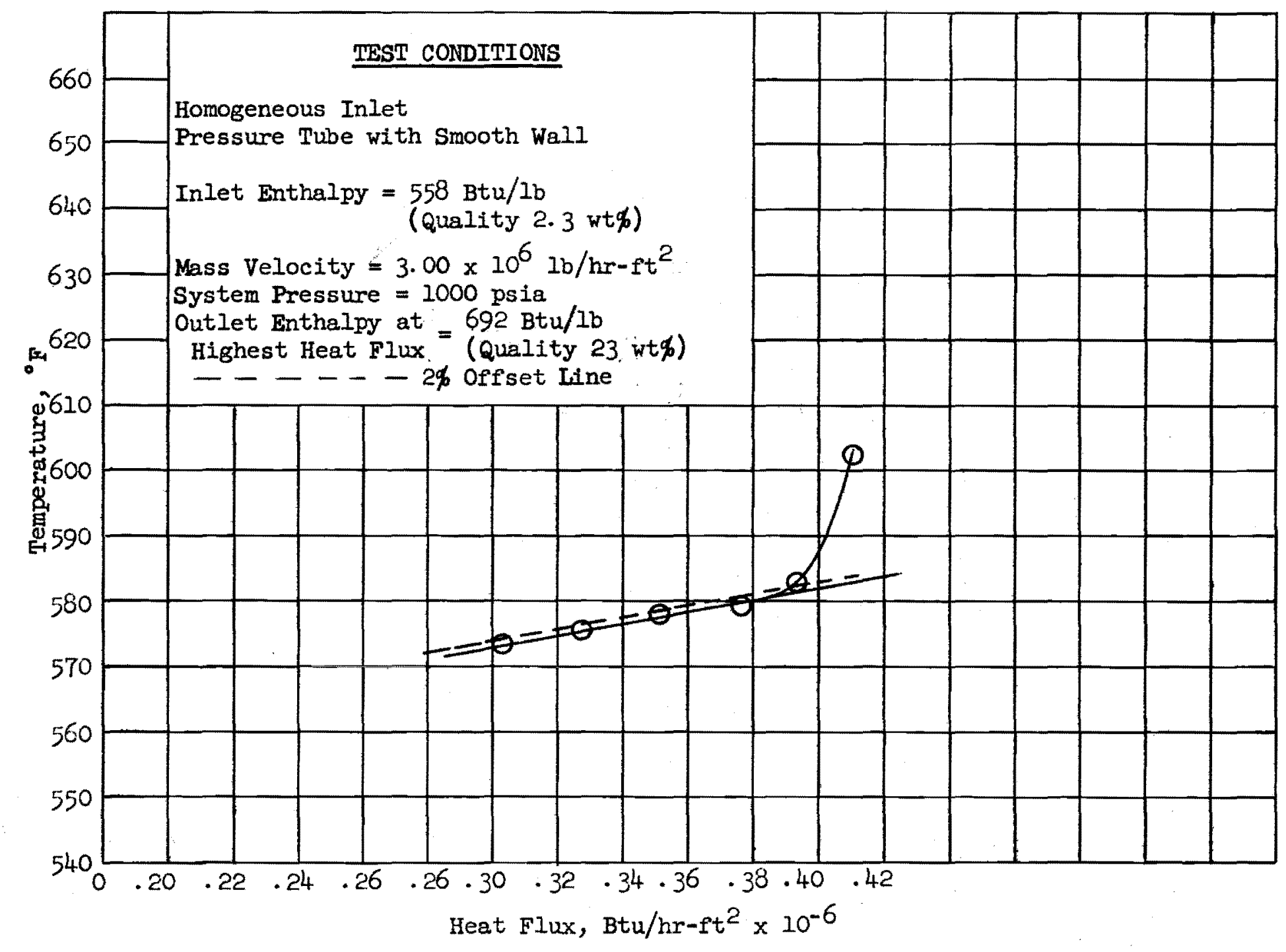

Figure 8.

Typical Rod Temperature Behavior Where a Large Sudden Excursion Occurred 


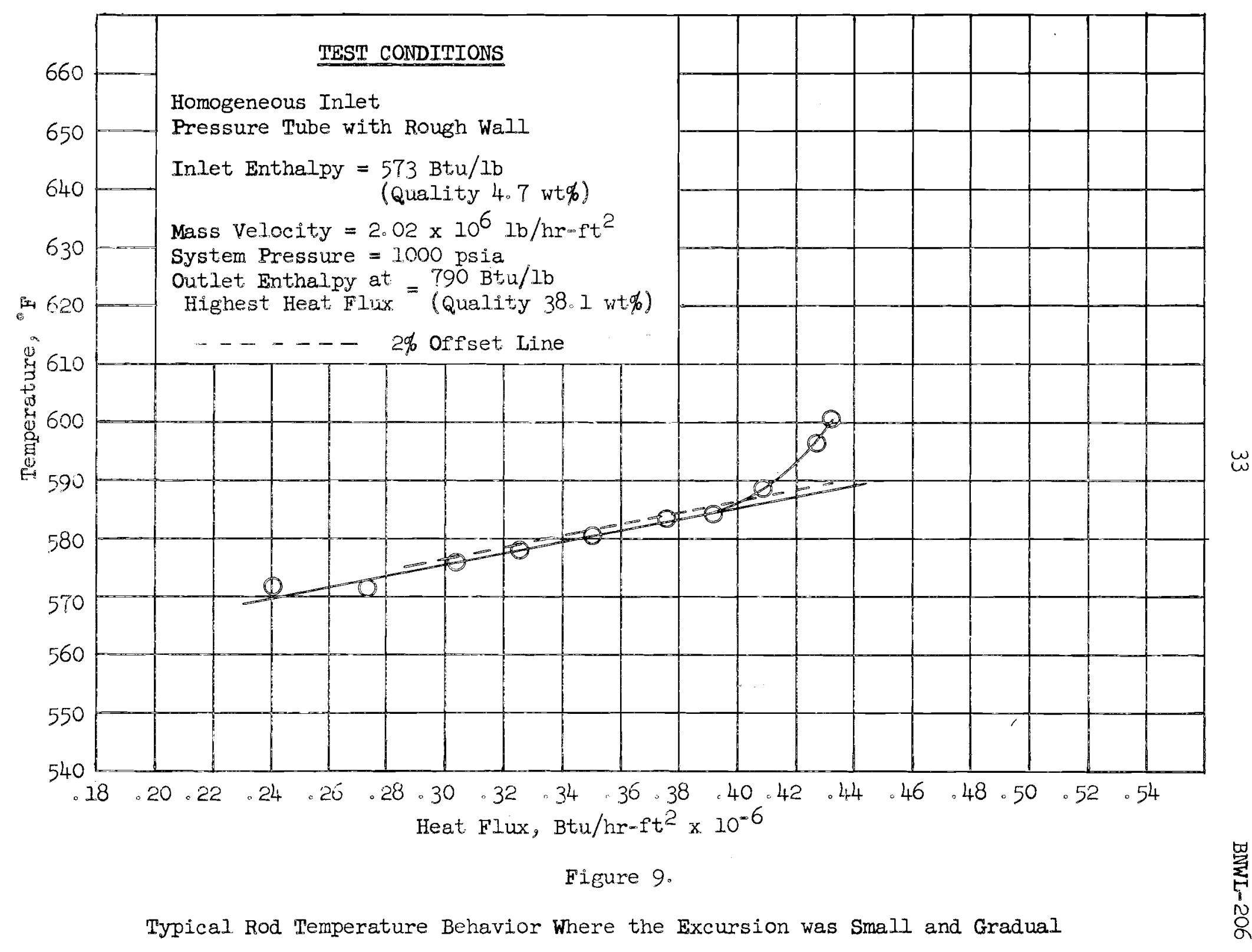




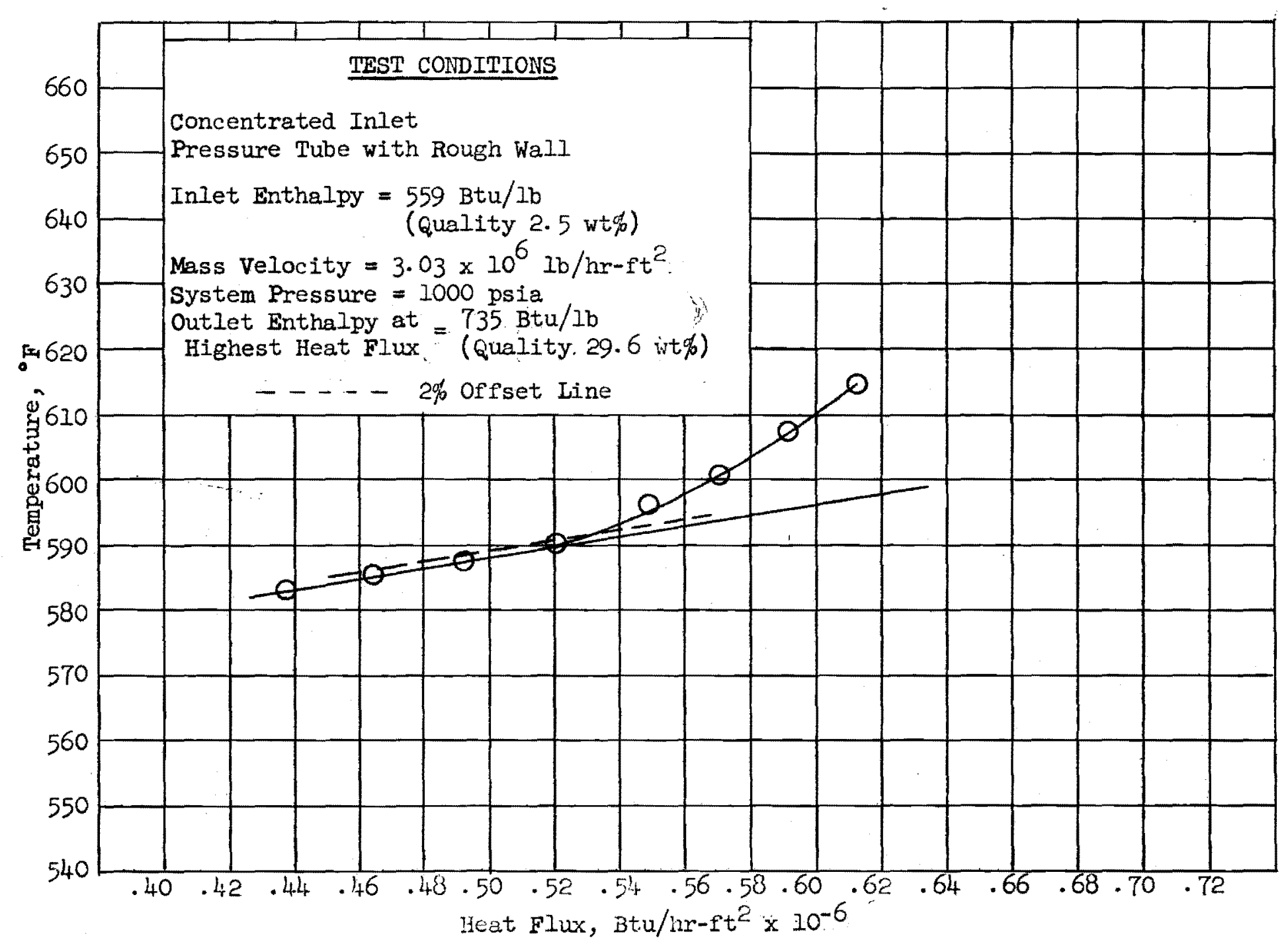

Figure 10.

Typical Rod Temperature Behavior Where the Excursion was Small and Gradual 


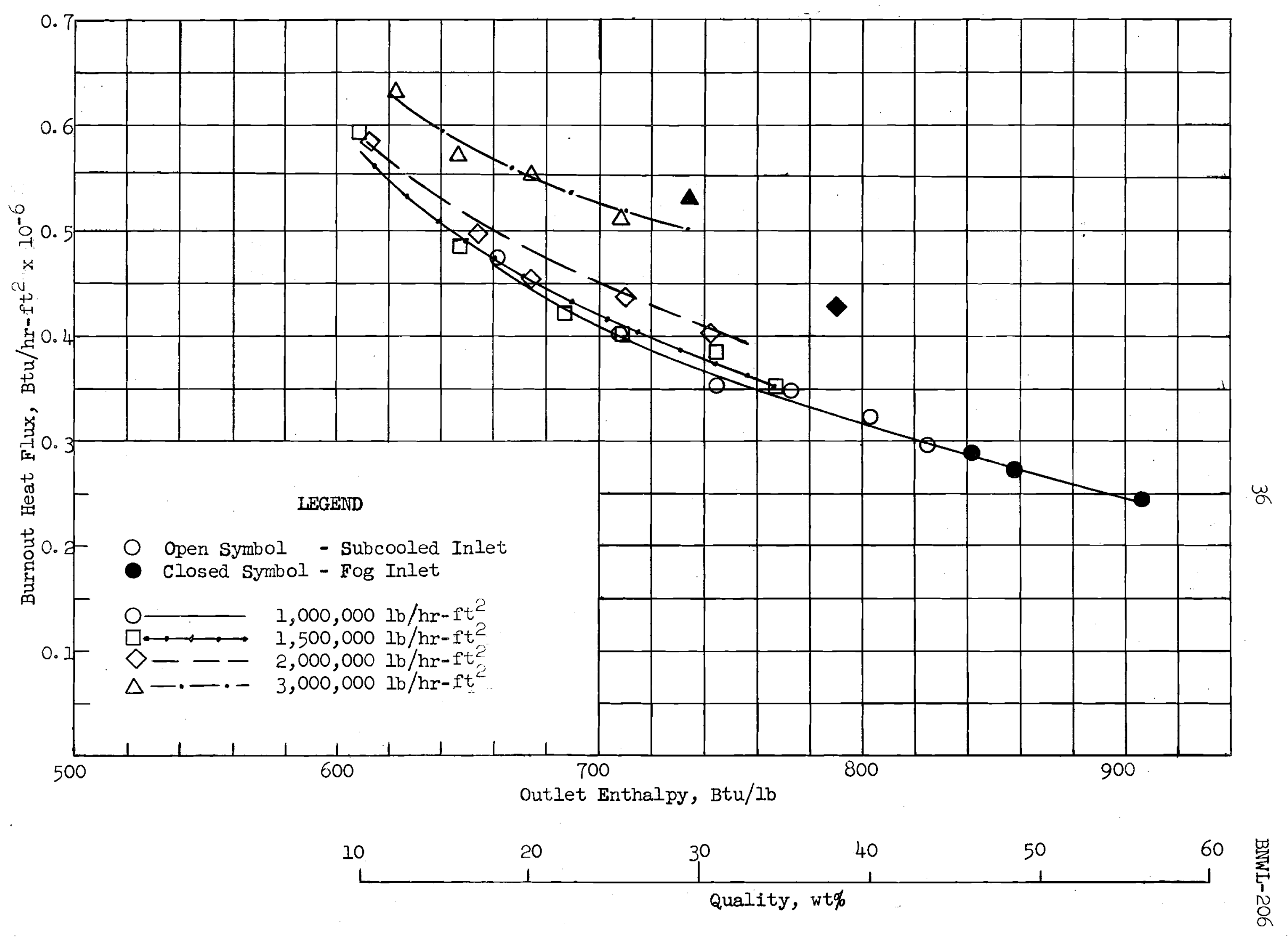

Figure 12. Boiling Burnout Results for Rough Wall Tube and 1000 psia 


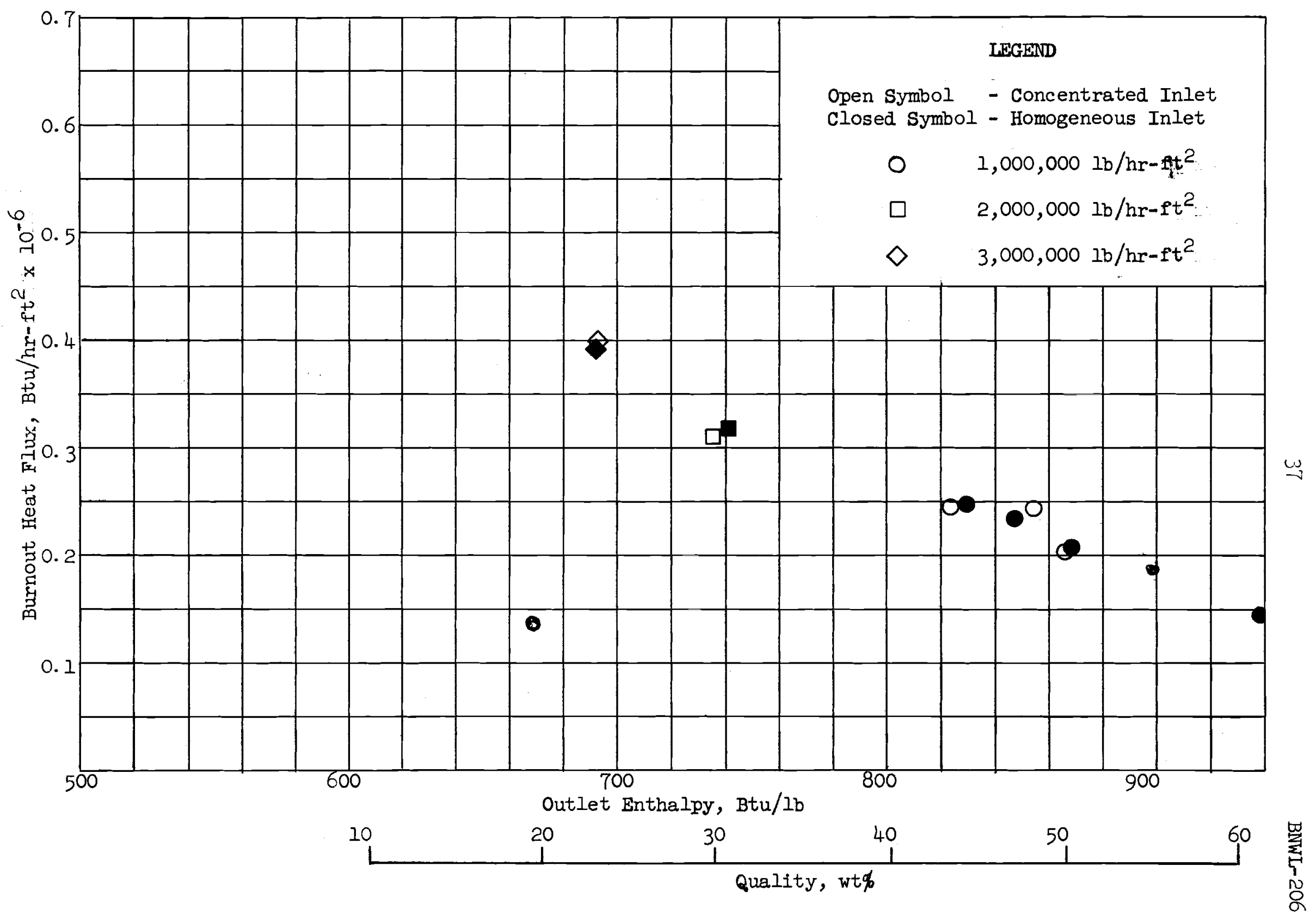

Figure 13. Effect of Concentrator on Boiling Burnout at 1000 psia and with Smooth Flow Tube Wall 


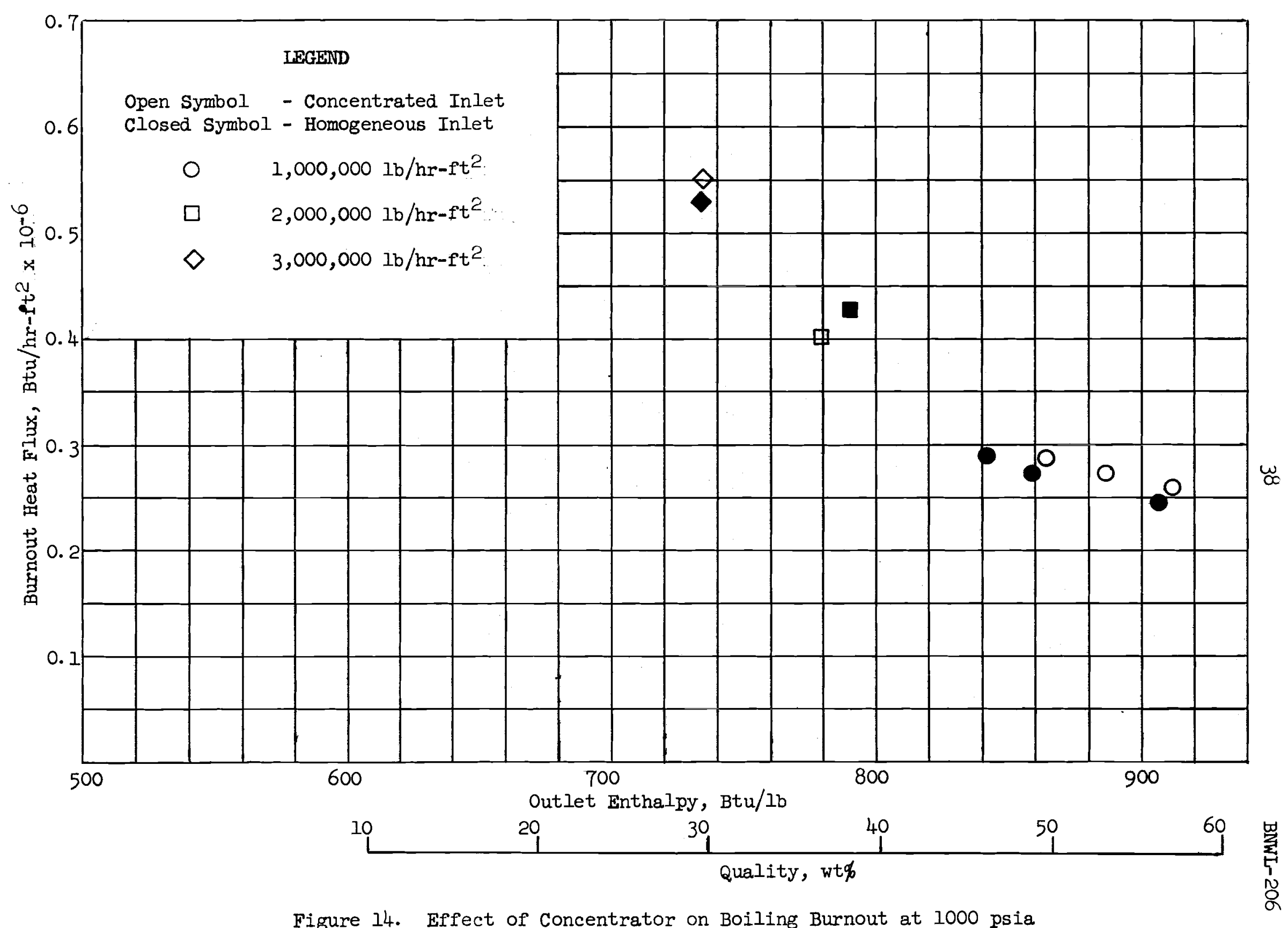

Figure 14. Effect of Concentrator on Boiling Burnout at 1000 psia and with Rough Flow Tube Wall 

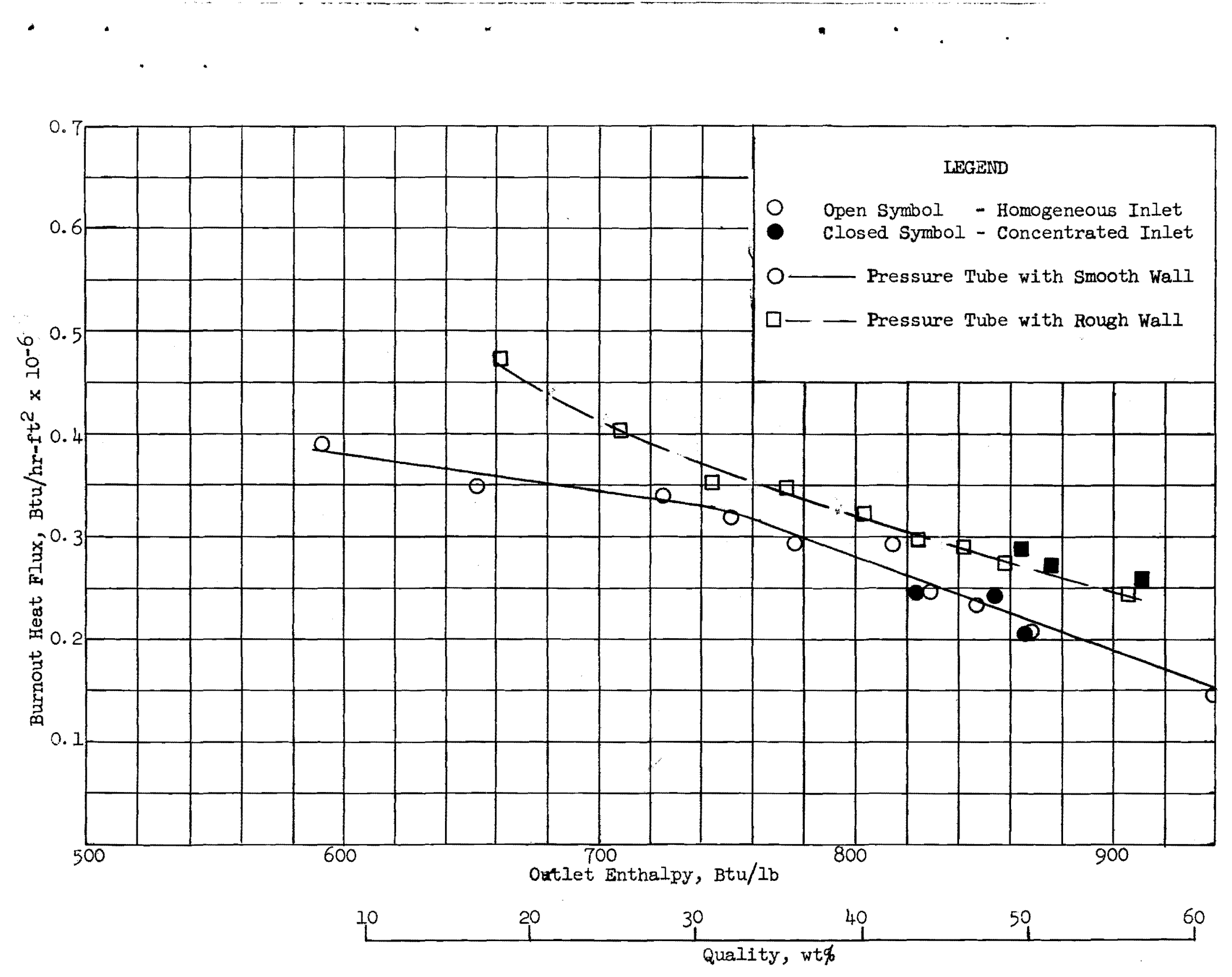

$\omega$

Figure 15. Effect of Rough Flow Housing Wall on Boiling Burnout at 1000 psia and a Flow Rate of $1,000,000 \mathrm{lb} / \mathrm{hr}^{-\mathrm{ft}^{2}}$ 


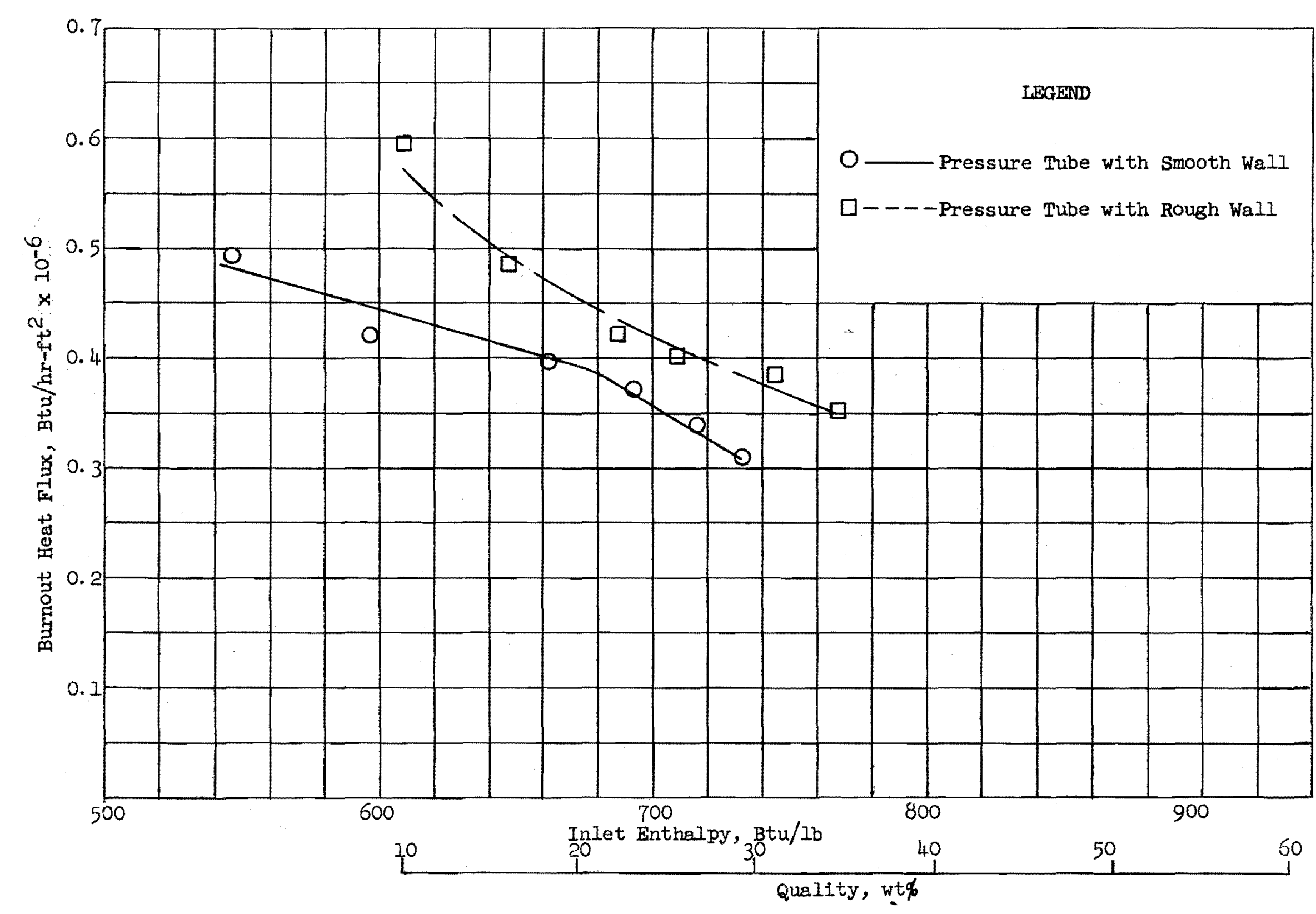

Figure 16. Effect of Rough Flow Housing Wall on Boiling Burnout at 1000 psia and a Flow Rate of 1,500,000 lb/hr-ft ${ }^{2}$ 


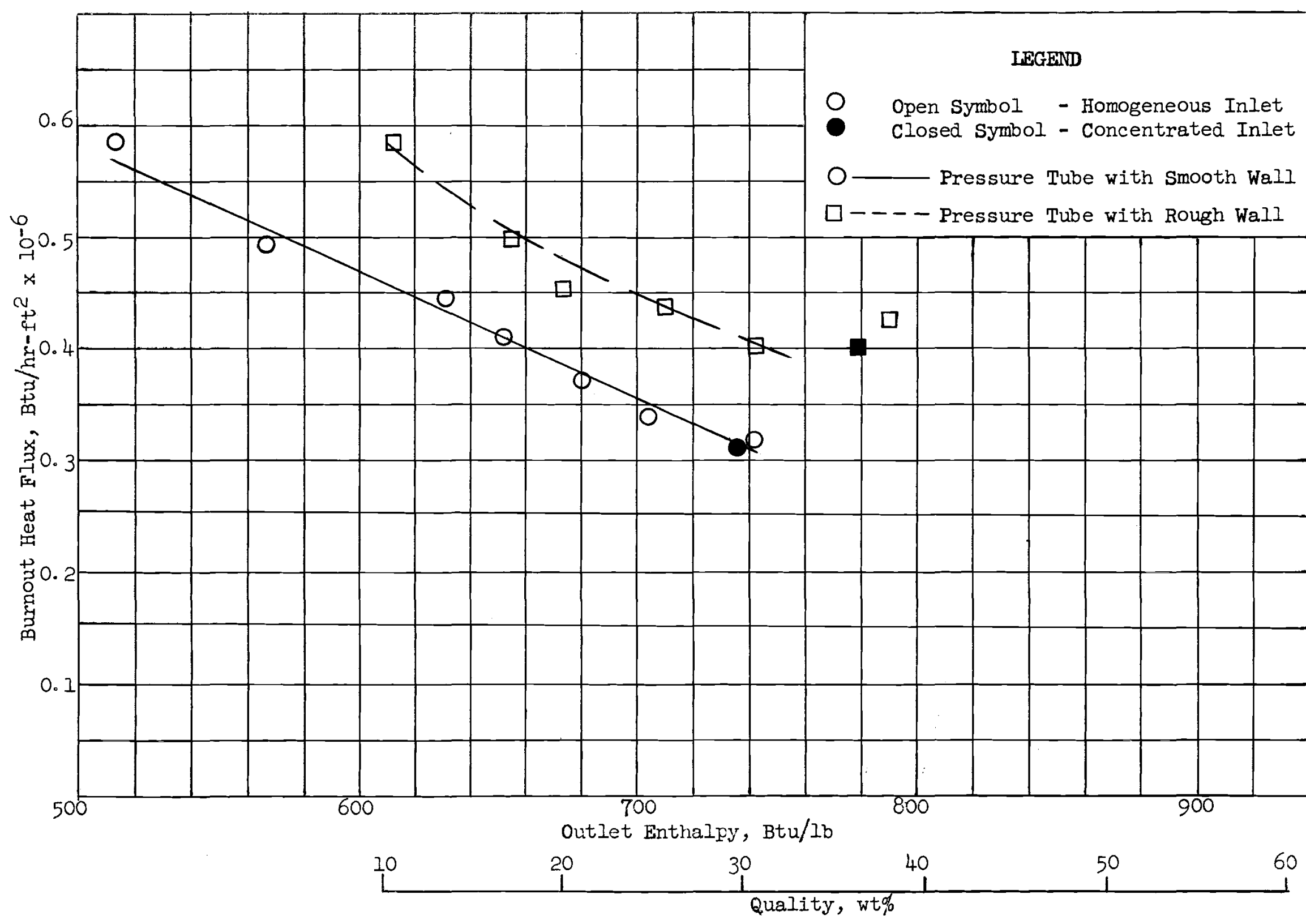

Figure 17. Effect of Rough Flow Housing Wall on Boiling Burnout at 1000 psia 


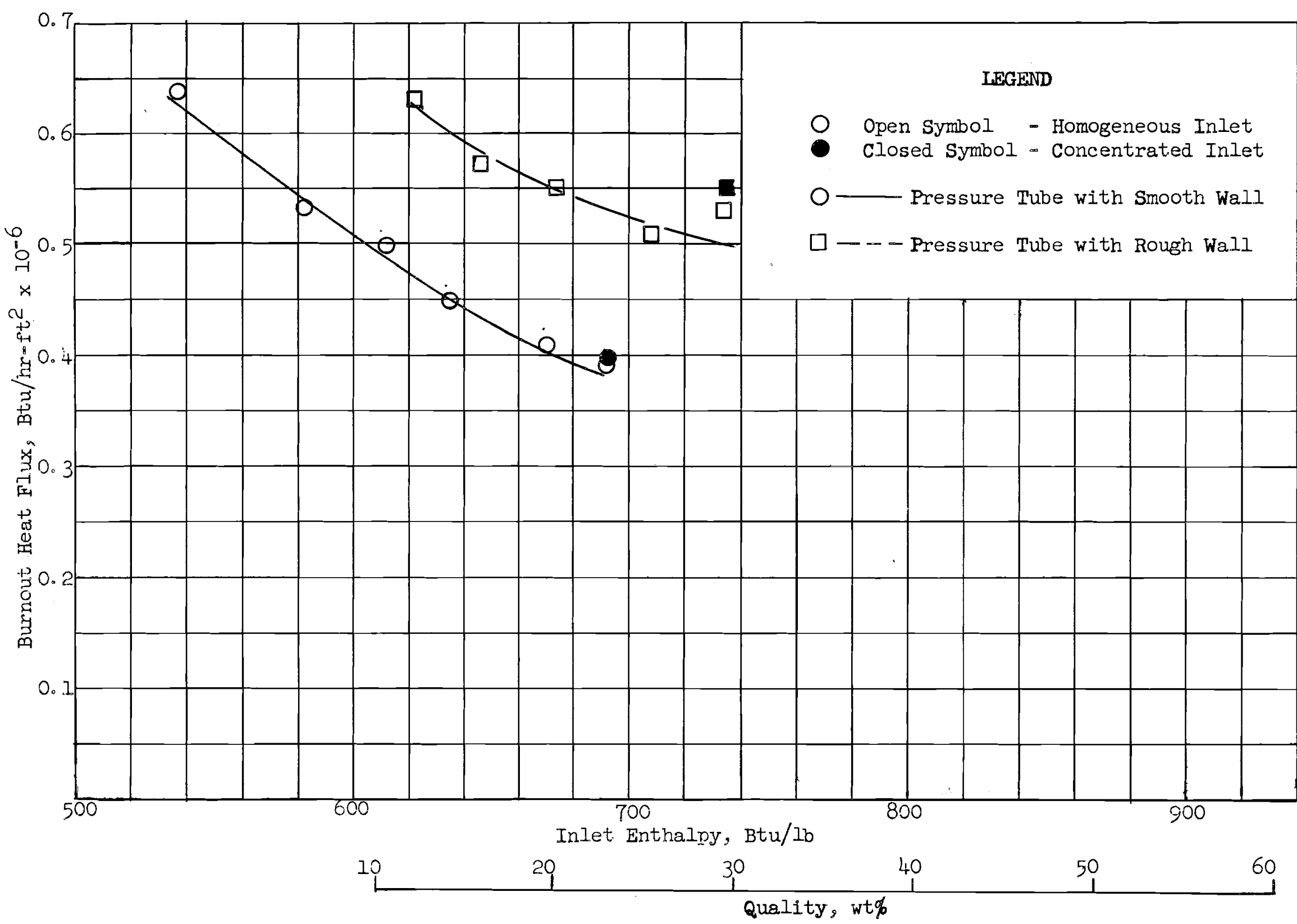

Figure 18. Effect of Rough Flow Housing Wall on Boiling Burnout at 1000 psia and a Flow Rate of $3,000,000 \mathrm{lb} / \mathrm{hr}-\mathrm{ft}^{2}$ 


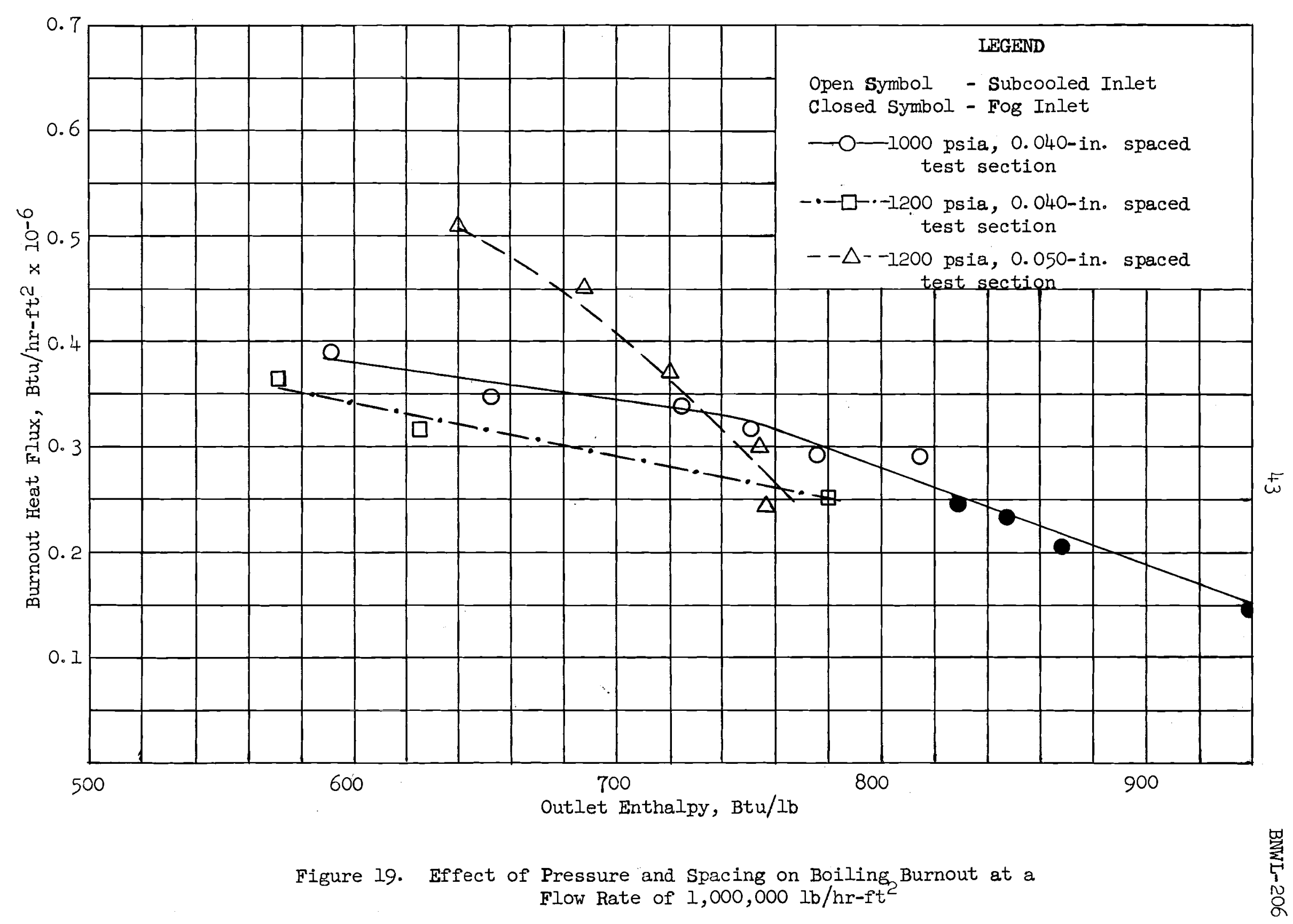




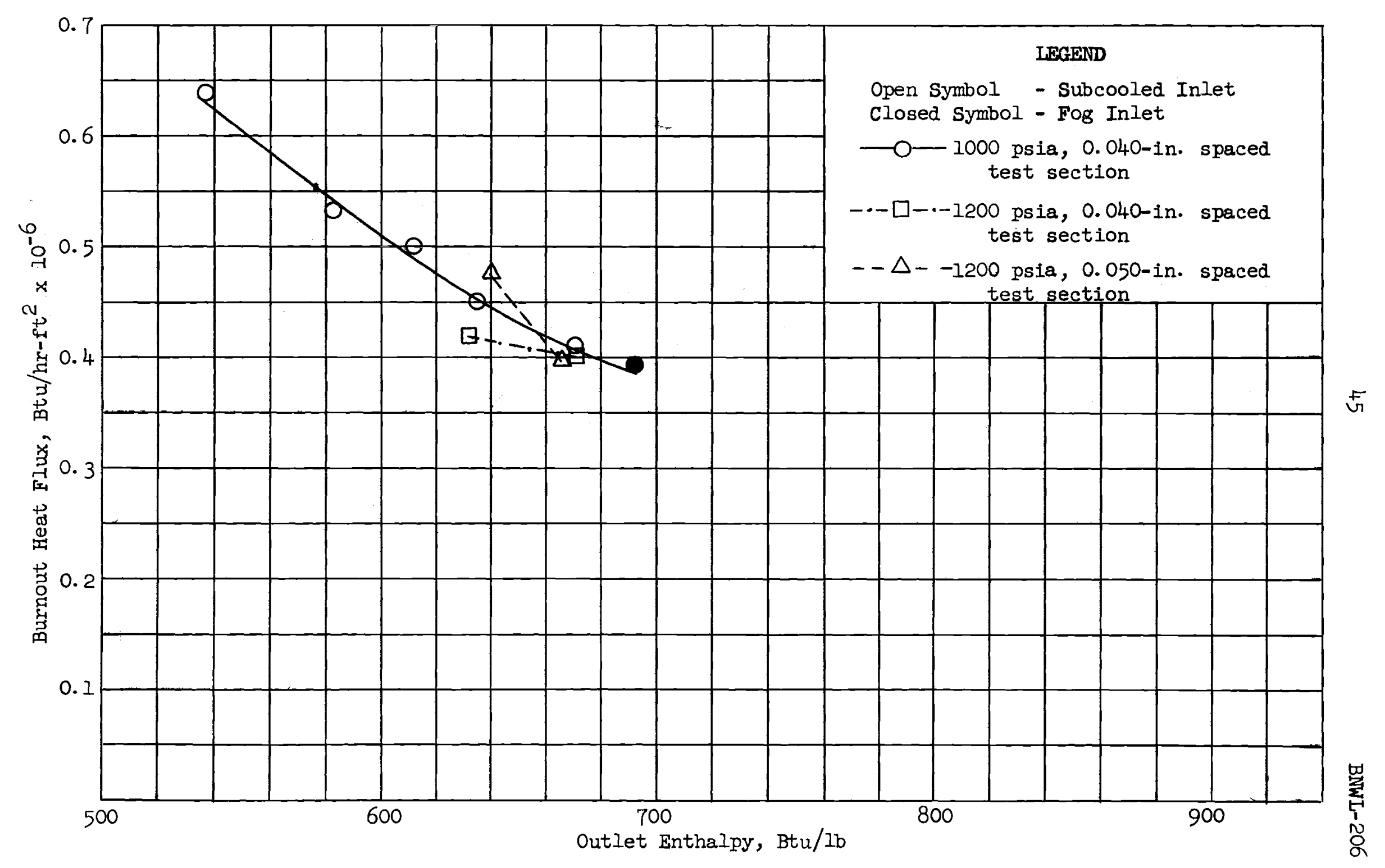

Figure 21. Effect of Pressure and Spacing on Boiling Burnout at a Flow Rate of $3,000,000 \mathrm{lb} / \mathrm{hr}-\mathrm{ft}^{2}$ 


\section{ONSITE DISTRIBUTION}

\section{Copy Number}

\section{Pacific Northwest Labcratory}

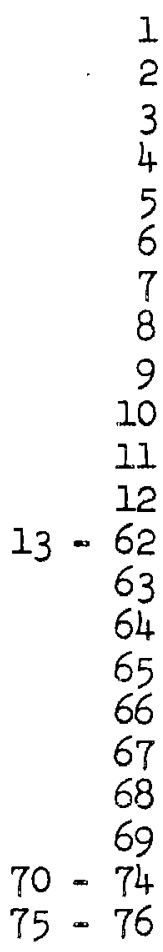

1

2

4

5

2

69

$75-76$

\section{Richland Operations Office}

$\begin{array}{llll}77 & \text { Po } & \text { Hoisted } \\ 78 & \text { Lo } & \text { Rucas } \\ 79 & \text { Ro } & \text { Ko Sharp }\end{array}$

\section{OFTSITE DISTRIBUTION (SPECIAL)}

No. of Copies

Atomic Energy Commission, Washington.

Attn: Ao No Tardiff, DRD\&N (3)

W. R. Voigt, DRD\&R (1)

Roland Ao Anderson

Asst General Counsel, Patents (1)

3 Atomic Energy Commission, SROO

Attr: Ro Io Morgan.

R. W. Ramsey

y。 H. Kruth 
OFFSITE DISTRIBUTION (SPECIAL) (continued)

\section{No. of Copies}

1

9

1

1

1

1

1

1

1

1

1

2

1

1

Atomic Energy Commission, Chalk River

Attn: Mo No Hudson

D. G. Boyer

USAEC Tech。Representative

Whiteshell, Pinawa

Manitoba, CANADA

G。 H. Lee

Chicago Patent Group

Office of Tech. Info.

Oak Ridge

D. F. Babcock

du Pont $=$ Wilmington

Jo $E_{0}$ Casterline

Columbia University

C. A. Trilling

Atomics International

Ralph Webb

Babcock \& Wilcox

Royce Rickert

Combustion Engineering

1 Ro Go McGrath

Westinghouse Electric Corporation

1 E。 Co Fiss

Carolinas-Virginia NPA

2 W. P. Overbecis

Savannah River Laboratory

Aerojet Gereral Nucleonics

P. D. Box 7?, San Ramon, Calif。

Attn: $\mathbb{K}$ Johnson

Allis Chalmers Manufacturing Co.

Atomic Energy Division

Milwaukee 1, Wisconsin

Attn: K. F。 Neusen 
OFFSITE DISTRIBUTION (SPECIAL) (Continued)

No. of Copies

2

Argonne National Laboratory

9700 South Cass Avenue

Argonne, Illinois

Attn: Dr. Paul Lottes

Dr. M. Petrick

1

Atlantic Research Nuclear Corp. Shirley Highway at Edsall Road Alexandria, Virginia

Attn: Dr. M. Markels, Jr.

Atomics International

P. 0. Box 309

Canoga Park, Califormia

Attn: Dr。 I. Bernath

$1 \quad$ Babcock \& Wilcox Company

1201 Kemper Street

Lynchburg, Virginia

Attn: Donald F。 Judd

1 Brookhaven National Laboratory

Upton, I. I., New York

Attn: Dr. O. E. Dwyer

1 Dartmouth College

Thayer School of Engineering

Hanover, New Hampsire

Attn: Dr. Graham B. Wallis

1 Dynatech Corporation

17 Tudor street

Cambridge, Massachusetts 02139

Attn: Dr. A. Bergles

2 General Electric Company

Atomic Power Equipment Dept.

175 Curtner Avenue

San Jose, Calif。

Attn: Dr。So Levy

2

General Electric Company

Advanced Technology Laboratory

Schenectady, New York

Attn: Dr。 Novak Zuber 


\section{OFFSITE DISTRIBUTION (SPECIAL) (Continued)}

No. of Copies

1

Geoscience Ltd.

8686 Dunaway Drive

Le Jolla, California

Attn: Dr. H. F. Poppendiek

2

Massachusetts Institute of Technology

Department of Mechanical Engineering

Cambridge 39, Massachusetts

Attn: Dr. W. M. Rohsenow

Dr. P. Griffith

National Aeronautics \& Space Administration

Lewis Research Center

21000 Brookpark Road

Cleveland 35, Ohio

Attn: R. Weltmann (SEPO) (2)

Library (3)

1

North Carolina State University

Department of Chemical Engineering

Raleigh, North Carolina

Attn: Dr. J. K. Ferrell

1

Oak Ridge National Laboratory

P. O. BOX Y

Oak Ridge, Tennessee

Attn: Dr. H. W. Hoffman

1 University of Minnesota

Department of Chemical Engineering

Minneapolis, Minnesota 55455

Attn: Dr. H. S. Isbin

1 Westinghouse Electric Corporation

Atomic Power Division

P. 0. Box 355

Pittsburgh, Pennsylvania 15230

Attn: Dr. I. S. Tong

1

U. S. Atomic Energy Commission

Division of Safety Standards

Washington, D. C. 20545

Attn: R. Impara 
OFFSITE DISTRIBUTION (SPECIAL) (Continued)

No. of Copies

5

U. S. Atomic Energy Commission

Division of Reactor. Development and Technology

Washington, D. C. 20545

Attn: R. M. Scroggins (2)

Office of Civilian Power

Water Reactors Branch (I)

Office of Army Reactors

Technical Evaluation Branch (1)

Office of Nuclear Safety

Research and Development Branch (1)

1

Atomic Energy of Canada Limited

P. O. Box 905

Toronto 18, Ontario, CANADA

Attn: W. B. Morison

1 Atomic Energy of Canada Limited

Chalk River, Ontario, CANADA

Attn: G. A. Wikhamer

1

Atomic Energy Establishment

Winfrith, Heath, ENGIAND

Attn: W. S. Eastwood

2

Atomic Energy Research Establishment

Harwell, Berkshire, ENGLAND

Attn: G. F. Hewitt

J. G. Collier (Nr. Didcot Berkshire)

1

Centre d'Etudes Nuclearies

Chemin des Martyrs

Grenoble (Isere), FRANCE

Attn: M. Mondin

1

CISE

Casella Postale 3986

Milano (Segrate), ITALY

Attn: Prof. M. Silvestri

1

MAN

Abholfach

Nurnberg 2 GERMANY

Attn: Dr. Mayinger 


\section{OFFSITE DISTRIBUTION (SPECIAL) (Continued)}

\section{No. of Copies}

1

1

1

1

1

1

1

1

1
SNECMA

Division Atomique

22, quai Gallieni

suresnes (Seine), FRANCE

Attn: M. Foure

Technische Hogeschool Eindhoven

P. 0. Box 313

Eindhoven, NETHERIANDS

Attn: Prof. Dr. M. Bogaardt

Compagnie Francaise

Thoms on-Houston

I, rue des Mathurins

Bagneux (Seine), FRANCE

Attn: Mo Lefranc

AEG-Kernenergieversuchsanlage

8752 Großwelzheim (Unterfranken)

GERMANY

Attn: Dr. Kirchenmayer

Alsthom

38 avenue Kleber

Paris 16e, FRANCE

Attn: M. P. Domenjoud

Centre d'Etudes Nucleaires de Saclay

B. Po $\mathrm{n}^{\circ} 2$

Gif-sur-Yvette (s\&o), FRANCE

Attn: Mo J. Horowitz

FIAT

Sezione Energia Nucleare

Via settembrini 235

Torino, ITALY

Attn: M. G. Cesoni

Reactor Centrum Nederland

112 Scheveningseweg

's Gravenhage, NETHERIANDS

Attn: Prof. Dr. M. Bogaardt

ANSALDO

Direzione Generale

Piazza Carignano 2

Genoa, ITALY

Attn: Dr. F. Cristofori 


\section{OFFSITE DISTRIBUTION (SPECIAL) (Continued)}

No. of Copies

2

EURATOM

Direction Generale $\mathrm{R}$ \& $\mathrm{E}$

51, rue Belliard

Bruxelles, BELGIUM

Attn: Dr. P. Kruys

1

EURATOM

Casella Postale 1

Ispra (Varese), ITALY

Attn: M. R. Morin

1 Canadian Westinghouse Co. Itd.

P. 0. Box 510

Hamilton, Ontario, CANADA

Attn: F. Stern

1 E. I. du Pont de Nemours \& Co.

de Nemours Building

Wilmington, Delaware

Attn: J. S. Neill

1 General Electric Company

Knolls Atomic Power Laboratory

Schenectady, New York

Attn: G. H. Halsey

$1 \quad$ Oak Ridge National Laboratory

P. O. Box Y

Oak Ridge, Tennessee

Attn: W. R. Gambill

$1 \quad$ Oregon State University

Corvallis, Oregon

Attn: Dr. J. G. Knudsen

$1 \quad$ Purdue University

Mechanical Engineering Department

W. Lafayette, Indiana

1 University of Virginia

Department of Nuclear Engineering

Charlottesville, Virginia

Attn: Prof. James Rust

1 University of Washington

Seattle, Washington

Attn: Dr. R. W. Moulton 


\section{OFFSITE DISTRIBUTION (SPECIAL) (Continued)}

\section{No. of Copies}

1

Westinghouse Electric Corporation

APD Bettis Field

P. 0. Box 1468

P1ttsburgh, Pennsylvania 15230

Attn: S. J. Green 